\title{
EL MEDITERRANI OCCIDENTAL AL DARRER QUART DEL SEGLE XIII: CONCURRÈNCIA COMERCIAL I CONFLICTIVITAT POLÍTICA
}

\author{
ANTONI RIERA I MELIS \\ Universitat de Barcelona
}

\author{
SUMARI \\ I. Introducció.- II. El context socioeconòmic.- III. Les relacions \\ internacionals.- IV. Conclusions.
}

\section{INTRODUCCIÓ}

L'aixecament dels sicilians contra l'Administració angevina i l'immediat suport ofert pels catalans a la revolta trenquen bruscament, el 1282, l'expansionisme del Regne de Nàpols a ambdues conques de la Mediterrània i la preponderància güelfa a Itàlia. L'entesa de Carles d'Anjou i la Santa Seu havia esfondrat els darrers vestigis de l'obra dels Staufen al Mezzogiorno i havia enfortit tant la presència francesa a la Mediterrània com la influència política del Pontificat a Itàlia i a la resta de l'Occident. Arran de la desaparició de Manfred i de Conradí van caure, a algunes ciutats del nord del Tíber, els governs gibel·lins.

L'annexió de Sicília reforça la presència econòmica i política de la Corona Catalano-aragonesa al centre del vell Mare Nostrum, afavoreix la penetració comercial dels catalans i dels mallorquins a Trinàcria, esperona l'hostilitat dels genovesos i provoca un redreç del gibel-linisme a Itàlia, que,

"Anuario de Estudios Medievales", 26 (1996) 
després de catorze anys de replegament, troba en Pere el Gran el coordinador extern que necessitava.

El front franco-angeví, amb el suport decidit de la Santa Seu, que excomunica Pere el Gran i llança una croada contre els seus estats, intenta recuperar per la força l'enclavament insular, tot desencadenant un conflicte internacional de vastes proporcions. Malgrat que la supremacia naval catalana i el neutralisme ligur col·loquen el bàndol güelf en una situació d'inferioritat militar, els costos de la guerra acabaran per convèncer tots els participants de la necessitat de buscar una sortida negociada al conflicte. La concentració del gros de la flota i dels efectius militars al Mezzogiorno impedia a la Monarquia aragonesa aprofitar les favorables perspectives d'expansió territorial que la complicada successió d'Alfons $\mathrm{X}$ de Castella obria, del 1289 ençà, a la Península Ibèrica. L'excomunió creava problemes institucionals i d'imatge al membres de la casa de Barcelona i generava un conflicte de fidelitats a la clerecia. La Santa Seu, per altra part, no podia recolzar infinitament $\mathrm{i}$ incondicional un estat que era incapaç de restablir els seu control damunt Trinàcria, la seva influència arreu d'Itàlia i el seu prestigi internacional.

Durant el primer semestre de 1295, els esdeveniments es precipiten: Jaume II, a canvi d'una renúncia a Sícilia i a les Illes Balears que no hi comprometia l'activitat mercantil dels seus súbdits i del rebuig dels plantejaments gibel-lins, obté l'aixecament de l'interdicte, el càrrec de defensor de l'Església i la infeudació de Sardenya. La guerra del Vespro sicilià, com a conseqüència dels acords d'Anagni, es tranforma de conflicte internacional en divergència regional.

En els tretze anys que separen la ruptura i el restabliment de relacions entre la Santa Seu i la Monarquia aragonesa, els pisans i els venecians reculen davant els genovesos al Tirrè i a Llevant respectivament, el Regne de Mallorca paga amb la pèrdua de l'arxipèlag balear la seva alineació amb el front franco-angeví i els mamelucs expugnen els darrers enclavaments cristians a Palestina.

L'objectiu d'aquest article consisteix en analitzar les relacions polítiques i mercantils que van mantenir, entre 1282 i 1296 , els principals estats riberencs del Mediterrani occidental, copsar les interferències que es van produir entre les respectives expansions econòmiques i territorials, identificar-ne les àrees de fricció, estudiar els procediments utilitzats pels concurrents per defensar-hi els seus interessos i escorcollar, finalment, la 
penetració i l'arrelament dels ciutadans dels centres expansius en els principals mercats d'ultramar.

\section{EL CONTEXT SOCIOECONÒMIC}

La Mediterrània, al darrer quart del segle XIII, esdevé l'àrea econòmica més desenvolupada de tot l'Occident, per tal com hi discorren la majoria de les principals vies mercantils de l'època. Cap el vell Mare Nostrum flueixen les espècies i la seda orientals, l'or i els esclaus negres de l'Africa subsahariana i els draps fins i la llana de qualitat de les riberes del Mar del Nord. S'ha convertit en l'àmbit des del qual els productes occidentals -els draps, els metalls, la fusta, el cordam, la pega- es difonen per Asia i Africa, i els articles asiàtics i africans penetren a l'Occident europeu.

La Mediterrània, pels volts del 1290 , no era, tanmateix, una àrea sense problemes. Al camp, després de més de dos segles d'expansió, hi emergeixen els primers símptomes de crisi ${ }^{1}$. El creixement de la producció agrària s'havia assolit preferentment mitjançant procediments extensius, tot eixamplant els espais conreats. Poc després del 1250, les grans rompudes es tanquen arreu de l'Occident; les artigues, cada cop més petites i discontínues, només progressen en alguns nuclis secundaris o perifèrics. Gairebé totes les terres conreables de manera permanent amb la tecnologia agrària de l'època ja estaven en explotació. Per tal com, si més no fins després del 1315, mentre les rotes cessen, la població continua creixent, encara que a un ritme lent, les explotacions es contreuen. A les àrees centrals, de colonització prematura, tanmateix, els sòls més prims i àrids, després de quinze o vint dècades de conreu, esdevenen, com a conseqüència d'una inobservança estricta - per afanys d'excedents comercialitzables, pressió senyorial o sobrecàrrega demogràfica- de les rotacions i d'un dèficit crònic d'adob i de llaurades profundes, improductius. La fragmentació dels masos i la caiguda de la productivitat provoquen que, a un sector creixent de la pagesia, el conreu de la pròpia explotació no li garanteixi ja l'autosuficiència alimentària i hagi de reduir el consum i cercar ingressos complementaris. Als confins

\footnotetext{
'Que he analitzat amb més detall a El context mediterrani de la primera fase del regnat de Jaume II (1291-1311): conflictivitat $i$ canvis, "Jaume II set-cents anys després", Alacant, en premsa.
} 
dels segles XIII i XIV, la pauperització avança pels camps europeus. Els pagesos més mancats de recursos sol-liciten préstecs a llarg termini, la pensió dels quals grava les seves explotacions amb tanta intensitat o més que els censos senyorials. Entre els prestamistes, sovint parents del prestatari, sobresurten el burgesos de la ciutat i, sobretot, els camperols més solvents de la comunitat. La difusió del crèdit entre la població rural genera relacions de dominació econòmica que erosionen les velles solidaritats vilatanes.

Moltes famílies pageses, incapaces d'assegurar-se el manteniment, demanen al seu senyor una reducció de cens propter sterilitatem terre ${ }^{2}$, quare dicta terra est modicum fructuosa ${ }^{3}$. L'arrest de les artigues i el descens de la productivitat en àmplies àrees de la terra de conreu provoquen una caiguda de les rendes senyorials, especialment als patrimonis en què predominen els agrers. Els grans propietaris, durant la fase de l'expansió, per tal d'omplir de pagesos llurs terres i estendre-hi els sementers, havien moderat les seves exigències. Ara, quan ja no disposaven de més terra conreable i les dificultats de moltes famílies pageses els obligava a reduir els censos, contemplen amb alarma com els seus ingressos, per primera vegada en molts d'anys, cessen de créixer, en una època que els preus dels articles de luxe i manufacturats pugen més de pressa que els dels productes agraris.

L'estament nobiliari, especialment el baix, el dels cavallers, malda per preservar els seus ingressos, per garantir a tots els fills una inserció social decorosa. Els senyors en bloc refermen els seus drets damunt la terra, incrementen la vigilància sobre la regular prestació de les rendes tradicionals, quan no intenten aconseguir, amb modificacions dels censos i serveis, allò que abans obtenien mitjançant la instal-lació continuada dels camperols als respectius dominis. La solució consistirà a definir amb precisió el concepte de lluïsme i els percentatges que corresponen al titular del domini directe en cada un dels casos en què es pot aplicar, i a acceptar les demandes de reduccions de censos dels seus pagesos, tot transformant-los de parciaris en fixos en espècie o, més sovint, en metàl-lic. La sobreexplotació dels pagesos no és, emperò, il·limitada, té un sostre, cosa que explica que, en molts de casos, les mesures esmentades no aconsegueixin redreçar les

\footnotetext{
${ }^{2} \mathrm{ACB}$, Pia Almoina, Administracions Foranes, perg. 4-112-8; cit. T. LóPEZ PIzCueTA, El patrimonio de la Pia Almoina de Barcelona en la época central del siglo XIV, Universitat de Barcelona, Facultat de Geografia i Història, 1995, exemplar multicopiat, p. 297, nota 181. 182.

${ }^{3}$ ACB, Pia Almoina, Administracions Foranes, perg. 4-131-99 b; cit. Ibidem, p. 297, nota
} 
entrades dels poderosos ni els alliberin d'haver de buscar, a l'Administració o a empreses exteriors, ingressos complementaris. Cavallers que es veuen obligats a reduir el nivell de vida, que ja no poden dissimular la contracció experimentada per les seves rendes, no constitueixen pas, pels volts del 1290, un exotisme enlloc de la Mediterrània occidental, ja que n'hi ha pertot arreu, des de València a Calàbria. La decidida participació de la baixa noblesa catalana a la llarga guerra de les Vespres Sicilianes devia obeïr, entre altres raons, a un afany de recuperar unes taxes de consum adients a la seva categoria social. Els censos fixos, per altra part, encara que inicialment puguin semblar més lleugers que els antics agrers, esdeven un autèntic calvari per a les famílies pageses els anys de males collites, cada cop més freqüents en unes explotacions on la restauració periòdica de la fertilitat esdevé més lenta i problemàtica.

Aquestes modificacions de les relacions entre senyors i pagesos coincideixen, altrement, amb un procés de centralització política, entorn de les Monarquies i les Repúbliques urbanes, que es traduirà en un augment de la pressió fiscal al camp. Les dificultats provocaran, tanmateix, respostes diverses al si de la pagesia. Algunes famílies camperoles, les més febles, obligades a comprimir simultàniament el consum i la inversió, s'esfondren econòmicament $\mathrm{i}$ abandonen les terres. Unes altres, amb més recursos, procuren incrementar l'estalvi, per tal de rescatar les prestacions personals i incrementar la seva autonomia econòmica i social.

Les secades, les pluges torrencials, les pedregades i les plagues, que entre 1150 i 1250 no havien provocat més que escassetat locals transitòries, generen ara, en abatre's damunt explotacions familiars mancades d'estalvi, desproveïments perllongats, penúries, fams i, fins i tot, mortaldats en extenses zones geogràfiques de la Mediterrània cristiana.

Les dificultats s'obriren amb la crisi de 1257-1260, quan la manca de queviures va provocar fam i importants moviments migratoris al districte de Luca, penúria a les rodalies de Florència, Parma i Mòdena, al Forez i a Castella, on un seguit de males collites, els darrers set anys, han provocat, segons els seus bisbes, qui divites erant facti sunt pauperes, et qui pauper, mortui sunt ${ }^{4}$, i escassetat a la Corona Catalano-aragonesa. Les males collites, les escassetats, les penúries i la fam reapareixen intermitentment,

${ }^{4}$ P. Linehan, La Iglesia española y el Papado en el siglo XIII, Salamanca, Universidad Pontificia, 1975, p. 156. 
durant la segona meitat del segle XIII, a Itàlia, França, la Península Ibèrica ${ }^{5}$ i, fins i tot, a Sicília ${ }^{6}$ i Nàpols ${ }^{7}$, els dos principals graners de l'àrea.

Les reiterades males collites i l'increment de les exigències senyorials i fiscals van provocar un gran malestar entre la pagesia, pel fet d'esdevenir-se quan les famílies masoveres, esperonades per la demanda del mercat, intentaven rescatar les velles obligacions, que consideraven anacròniques $\mathrm{i}$ incompatibles amb l'augment de la producció. El primer símptoma de desassossec va consistir en l'abandonament de les terres, una iniciativa que, per les dimensions que va assumir, es configura com un autèntic mecanisme de protesta contra la pressió dels terratinents i del fisc. La deserció camperola va adquirir especial intensitat a la Calàbria. La pèrdua de força de treball va assolir també especial intensitat a l'alta Provença, on moltes famílies, davant les negres perspectives de futur, opten per marxar cap a zones més fèrtils o vers les ciutats.

La renúncia al mas no va ser l'única modalitat de contestació dels estaments baixos rurals, que no van dubtar, en algunes àrees, a passar a la revolta oberta contra els senyors i contra els mateixos agents reials. Anys difícils per al bloc feudal van ser, al Mezzogiorno, el 1276 i el 1277, quan es va poduir una revolta per tots els territoris continentals del Regne de Nàpols. Les notícies relatives a avalots esdeven més freqüents a les primeres dècades del segle XIV. D'estalvis d'assalts dels propis homes no hi estan ni els senyors eclesiàstics. Les revoltes antifeudals no queden circumscrites al Regne de Nàpols, esclaten també, encara que menys sovint, en altres àrees d'Itàlia, com a la Umbria. Es tracta normalment d'explosions de ràbia contra feudataris especialment exigents, són rars els casos en què els revoltats formulin un autèntic disseny polític, contestant la legitimitat del poder dels senyors o dels agents reials.

\footnotetext{
${ }^{5}$ Com he demostrat a Els pròdroms de les crisis agràries de la Baixa Edat Mitjana a la Corona d'Aragó. 1: 1250-1300, "Miscel.lània en Homentge al P. Agustí Altisent", Tarragona, Diputació Pronvincial, 1991, pp. 35-72.

${ }^{6 " E t}$ in predicta insula, que consuevit ex fertilitate sua omnibus vicinis et etiam loginquis victualia ministrare, fuit penuria maxima victualium; unam salmam frumenti valuit in ea, et aliquibus locis ipsius insulae, racione centum et ultra et, ubi minus valuit, valuit tarenos XL, cum ipsa insula comuniter salma frumenti valere consueverit tarenos tribus usque in sex" [N. GuerCII-G. DE MURTEDo-E. DroCI-B. Ususmaris, Annales Ianuenses. Anni MCCLXVIIMCCLXIX, "Annali Genovesi di Caffaro e de' suoi continuatori", ed. C. Imperiale di Sant'Angelo, IV, Roma, Istituto Storico Italiano, 1926, p. 122].

${ }^{7}$ C. ImPeriale di SANT'Angelo, "Annali Genovesi", IV, p. 126, nota 2.
} 
Contemporàniament a les fuites dels camperols de les explotacions i a les revoltes armades contra els senyors i l'autoritat reial, els documents de la cancelleria angevina reflecteixen una alça espectacular del bandidatge al Mezzogiorno. Durant el regnat de Carles II (1285-1309), tot coincidint amb la segona fase de la guerra del Vespro sicilià, l'Administració angevina, desbordada, va intentar descarregar una part de la tasca de persecució dels malandrini sobre les comunitats locals, que van haver d'assumir la vigilància de camins i passatges. Es durant la segona dècada del segle XIV, emperò, quan el fenomen del bandolerisme coneix una autèntica explosió, tant pel nombre d'integrants com per l'alt grau d'organització interna dels bàndols, que els permetien desencadenar ja atacs prolongats contra grans centres urbans.

Malgrat que els camperols revoltats contra els senyors o el fisc, els que han abandonat les explotacions i els que ha buscat en el bandidatge una sortida a la desesperació no tendeixen a unir els seus esforços per tal d'aconseguir, conjuntament i a curt termini, una reestructuració de la societat, ni tan sols una millora global de les condicions de vida dels estaments baixos rurals, la seva acció provocarà al llarg del segle XIV, si més no a les àrees amb menor pressió demogràfica i als períodes de debilitat del poder central, efectes positius per als pagesos. El record de les explosions de la còlera camperola i dels masos deserts induirà els senyors a mostrar-se quelcom més moderats amb la mà d'obra rural, a permetre que les relacions socials i econòmiques es plasmin per escrit, en estatuts locals.

Als nuclis urbans, la situació, encara que tibant, no era tan fosca, ja que hi persistia el ritme ascendent del gran comerç, de les transaccions exteriors. Els genovesos, vers 1280, estableixen una ruta naval entre la Mediterrània occidental i el Mar del Nord. La via de Gibraltar, sovintetjada prest pels venecians, mallorquins i catalans, agilitzarà considerablement els intercanvis entre aquestes dues grans àrees comercials, entre aquests dos importants àmbits econòmicament complementaris. La nova ruta atenuarà la circulació de mercaderies pels itineraris continentals que connectaven el Llenguadoc i la Provença amb les riberes del Mar del Nord i accelararà el declivi de les Fires de Xampanya.

L'expugnació, el 1291, de l'enclavament cristià d'Acre pels mamelucs provoca una forta rèplica antiislàmica per part de la màxima jerarquia eclesiàtica: Nicolau IV prohibeix tota mena de comerç amb els musulmans. El vet pontifici obliga els emporis de la Mediterrània Occidental a reestructurar la seva presència comercial a Llevant. Els homes de negocis 
lígurs, ben implantats, des del tractat del Nimfeu, al recentment restaurat Imperi grec, accentuen la seva penetració als mars Egeu i Negre. Els venecians, els catalans, els occitans i els provençals, més vinculats a Egipte i Síria, són els grans perjudicats per les noves restriccions mercantils i es veuen obligats a transferir, durant la darrera dècada del segle XIII, una bona part del comerç que fins llavors havien efectuat amb Alexandria i Damasc als estats cristians de Xipre, Rodes i la Petita Armènia. Les autoritats dels països occidentals afectats inicien, paral-lelament, gestions diplomàtiques davant la Santa Seu per tal d'atenuar la interdicció, tot restaurant l'antiga distinció entre mercaderies prohibides i lícites, i aconseguir una participació activa en la persecució judicial del tràfic clandestí i en les sancions pagades pels condemnats. La interferència eclesiàstica en el comerç amb l'Islam esdevindrà, després del 1300, un cost afegit, una taxa addicional, que gravarà les transaccions renovades amb aquest important intermediari.

L'establiment d'una ruta naval amb el Canal de la Mànega i les restriccions als contactes mercantils amb els musulmans contribuiran, al començament del segle XIV, a equilibrar el comerç exterior dels emporis de la Mediterrània Occidental, escorat, fins a la caiguda d'Acre, cap a Llevant.

L'ampliació gradual de la capacitat de càrrega dels vaixells i la baixada subsegüent de la quantia dels nòlits afavoriran la circulació comercial d'articles pobres no imprescindibles -alum, fusta, cuirs, terrissa, draps i llana bastos-, mercaderies que només poden suportar els costos de transport si viatgen en gran contingents $i$ amb nòlits reduïts. Aquesta combinació de fets, ben documentats, demostra que el comerç gaudeix d'una palesa capacitat de reacció i que la tecnologia naval i portuària de l'època és capaç d'aportar solucions, poc espectaculars però adients, a les noves necessitats.

El desenvolupament del comerç estimula la manufactura urbana. Es per aquesta època que, amb les importacions sistemàtiques de llana anglesa i amb la depuració gradual de les tècniques de producció, s'enlaira la draperia fina a les ciutats mediterrànies i hi prospera la de qualitat intermèdia, ja existent. Coetàniament al sector tèxtil, es desvetllen -sense assolir, tanmateix, les seves cotes de desenvolupament- els rams de la pell, la fusta, la terrissa i els metalls.

La prosperitat econòmica, el creixement de la fiscalitat i les primeres escassetats frumentàries havien desvetllat, a mitjan segle XIII, entre els mercaders i menestrals, organitzats ja en corporacions d'oficis, l'afany de participar en el govern municipal, un àmbit reservat fins llavors a l'aris- 
tocràcia i als grans homes de negocis, un col-lectiu aleshores molt restringit. Els objectius d'aquesta ofensiva política de les capes mitjanes urbanes apuntaven a assolir una distribució més equitativa de la càrrega tributària, a tallar l'especulació amb els queviures i les matèries primeres, i a presionar a la baixa les taxes d'interès dels préstecs. Els aixecaments urbans, iniciats als grans centres tèxtils flamencs, es van estendre prest cap a les ciutats italianes -Parma (1255), Bolonya (1256), Milà (1258), Siena (1262) i Florència (1266 i 1282)-, pel Carcí -Cahors (1270) - i Catalunya - Barcelona (1285) - . Durant els vint anys compresos entre 1290 i 1310, les capes mitjanes urbanes, el popolo grasso, amb el suport de les baixes, el popolo minuto, de qui recullen algunes reivindicacions, aconsegueixen, no pas sense tensions, arrencar una part del poder local als poderosos, els magnati.

D'entre les ciutat-estats de la Itàlia septentrional, Gènova és la que presenta una dinàmica històrica més original. El Popolo, a la capital de la Ligúria, s'havia començat a organitzar corporativament i política ${ }^{8}$, del 1258 ençà, sota la capitania de Guglielmo Boccanegra ${ }^{9}$, com es desprèn de la creació del Consiglio dei Anziani, una assemblea consultiva integrada per trenta-dos membres, alguns dels quals elegits entre les capes populars benestants ${ }^{10}$. L'experiment va tenir, emperò, una curta vigència, per tal com Guguielmo Boccanegra, el 1262, va ser deposat per un aixecament nobiliari güelf, encapçalat pels Grimaldi, que va abolir les seves reformes administratives ${ }^{11}$. No va ser, emperò, fins després del 1270 , durant la llarga Diarquia gibel-lina Doria-Spinola ${ }^{12}$, quan la burgesia mercantil i

\footnotetext{
${ }^{8}$ Alguns representants dels mercaders i dels menestrals, el 1261, subscriven ja, en representació dels estaments populars, al costat dels nobles, l'important tractat del Nimfeu: V. Vitale, Breviario della Storia di Genova, I, Genova, Società Ligure di Storia Patria, 1955, p. 79.

${ }^{9}$ R.S. LÓPEZ, Studi sull'economia genovese nel Medio Evo, Torino, S. Lattes, 1936, p. 150.

10 "Sequenti vero die, more aliorum capitaneorun, fuerunt electi de populo anciani .XXXII., videlicet quatuor per qualibet campagnam, ut quicquid cum eis seu eorum consilio faceret, disponeret vel ordinaret, vel cum maior parte ipsorum, ratum esset, possetque capitula cum eorum consilio concedere et contradicta corrigere et emendare et mutare": Annales Ianuenses. Anni MCCLI-MCCLXIV, "Annali Genovesi", IV, p. 26.

"Annales Inanuenses. Anni MCCLI-MCCLXIV, "Annali Genovesi", IV, pp. 46-47.

${ }^{12}$ Sistema de govern regit per dos Capitani, càrrecs ocupats simultàniament per sengles membres dels dos principals casals del gibel-linisme local. Les esmentades diarquies van ser cinc, agrupades en tres períodes: Oberto Doria i Oberto Spinola (1270-1285), Corrado Doria i Oberto Spinola (1285-1291), Corrado Doria i Corrado Spinola (1296-1297), Lamba Doria i Corrado Spinola (1298-1299), i Bernabò Doria i Opicino Spinola (1306-1309). Aquest
} 
menestral va aconseguir crear la primera plataforma d'intervenció política, la Societat dels Sants Apòstols Simó i Judes ${ }^{13}$. La direcció d'aquesta assemblea, integrada per un nombre elevat de membres, va ser confiada a un abat ${ }^{14}$, assessorat per un consell restringit, els Conestabuli. Les atribucions de l'Abbas Populi no van ser, tanmateix, ben especificades; sembla que no va disposar de jurisdicció pròpia ni va tenir una participació important en la gestió del Comú, ja que només hi va intervenir esporàdicament en defensa dels interessos dels estaments populars ${ }^{15}$. Alguns membres de les capes intermèdies es van integrar al Consell General, que va perdre atribucions en favor d'una altra assemblea consultiva, més restringida, els Anciani Comunis et Populi. Malgrat que l'ascendència social dels Anciani, els principals col-laboradors dels dos capitans en les tasques de govern ${ }^{16}$, no ha pogut ser encara establerta amb precisió, la majoria dels historiadors consideren la Diarquia gibel-lina com un sistema que va permetre a un conjunt de consorterie nobiliàries, amb el suport d'un ampli sector del poble, regir la República - des del 1270 fins al 1309- amb uns poders molt amplis, gairebé il-limitats. La quota efectiva de poder assolida pel poble va ser, doncs, molt inferior a la que li corresponia pel seu pes demogràfic i econòmic. L'especial estructura social de la Ligúria, amb una aristocràcia molt forta ${ }^{17}$, coordinada per quatre alberghi $i^{18}$, els Doria i els Spinola,

interessant període de la història lígur -les principals fonts coetànies del qual son el annals de Iacopo DoRIA [Annales Ianuenses. Anni MCCLXX-MCCLXXXXIII", "Annali Genovesi" , V, 1929, pp. 1-177] i de Giorgio STELLA [Annales Genuenses. Ab anno MCCXCVIII usque ad finem anni MCCCCIX, ed. L.A. Muratori, "Rerum Italicarum Scriptores", XVII, Milà, 1730, cols. 954-1317]- ha estat ben estudiat per G. CARO [Genova e la supremazia sul Mediterraneo (1257-1311), Genova, Società Ligure di Storia Patria, 1975, I, pp. 241-398, i II, pp. 9-369], V. VITAle [Breviario della Storia di Genova, I, pp. 86-87] i, més recentment, per A. Goria, Le lotte intestine in Gènova tra il 1305 e il 1309, "Miscellanea di Storia Ligure in onore di Giorgio Falco", Milano, 1962, pp. 252-280].

${ }^{13}$ Que va prendre el nom dels sants festivats el jorn de l'aixecament antigüelf: G. CARO, Genova sul Mediterraneo, I, p. 264

14" Populus unum haberet rectorem, qui super quibusadam sibi ministrans justiciam, Abbas Populi dicebatur": G. STELLA, Annales Genuenses, col. 1002.

${ }^{15} \mathrm{G}$. CARO, Genova sul Mediterraneo, I, pp. 264-265.

${ }^{16} \mathrm{G}$. CARo, Genova sul Mediterraneo, I, pp. 269-272.

${ }^{17}$ Que, malgrat disposar de béns rurals, de fortaleses, d'una munió de vassalls i de milícia privada al contado, s'havien sabut adaptar, sense renunciar als seus senyals d'identitat originaris, a la "revolució comercial" medieval, a l'economia monetària. Aquestes àmplies i poderoses famílies nobiliàries, al darrer quart del segle XIII, vivien a la ciutat, on esmerçaven en la construcció naval, el cors, el gran comerç i l'especulació urbanística els excedents de capital extrets de les seves extenses senyories. Els seus membres més conspicus, com Benedetto 
gibel·lins, i els Fieschi i els Grimaldi, güelfs, amb un escàs desenvolupament de la manufactura i una tardana aparició de les corporacions d'ofici ${ }^{19}$, explica el feble paper polític que hi va jugar, al darrer terç del segle XIII i primer del XIV, el poble.

En els períodes de forta tibantor interna, del 1291 al 1296 i entre 1300 i 1303, quan les dues estirps gibel-lines esmentades no aconseguien

Zaccaria [R.S. LÓPEZ, Genova marinara nel Duecento: Benetto Zaccaria, Milano-Messina, 1933], alternaven contínuament el comerç, el cors i la guerra [R.S. LóPEZ, El comercio en la Europa Medieval: el Sur, "Historia Económica de Europa", dirg. J. Clapham i E. Power, Madrid, Revista de Derecho Privado, II, 1967, pp. 373-374. Y. RENOUARD, Gli uomini d'affari italiani del Medioevo, Milano, Rizoli, 1973, p. 142; D. WALEY, Las ciudades-república italianas, Madrid, Guadarrama, 1969, p. 24; Ph. JONES, La storia economica. Dalla caduta dell'Impero Romano al secolo XIV, "Storia d'Italia" coordinada da R. Romano e C. Vivanti, II-2, Torino, Einaudi, 1974, pp. 1768, G. JeHEL, Les Génois en Mediterranée, pp. 180-186], una actitud que els permetia conservar intacte el patrimoni familiar - a l'explotació del qual aplicaven la mentalitat innovadora, pragmàtica i racionalista de la burgesia - i acumular capital financer. L'estament oligàrquic lígur, a la darreria del dos-cents, no actuava com un col.lectiu tancat sinó que es renovava constantment. Les grans fortunes mercantils, emergides del poble, hi tenien accés, després d'un procés d'adaptació dels models de vida aristocràtics, sense que això signifiqués que aconseguissin fusionar-se amb les velles i prestigioses estirps. Unes barreres subtils separaven les nissagues antigues (els Doria, Spinola, Grimaldi, Fieschi, etc.) de les de la nova "aristocràcia popular", com els Giustiniani [Ph. JONES, La Storia economica, p. 1791]. La república, per altra part, va procurar afavorir aquesta tendència, animant tots els que disposaven de patrimoni suficient a armar-se cavallers [OBERTO CANCELLIERE, Annales Ianuenses, ed. C.Imperiale di Sant'Angelo, "Annali Genovesi", I (1890), pp. 258-259. D. WALEY Las ciudades-república, p. 43].

${ }^{18}$ Institució típicament genovesa $\mathrm{i}$ molt original, consistia en un conjunt de nobles que, provinents de diverses famílies, porten el mateix cognom. L'organització, força rígida, i l'alta cohesió interna conferien a l'albergho una fermesa particular. La primera referència cronística data del 1265 [L. PignOLI, G. DE MULTEDO, M. UsuSMARIS i H. MARCHIONIS DE GAVIO, Annales Ianuenses. Anni MCCLXIV-MCCLXV, "Annali Genovesi", IV, Roma, 1926, p. 71] Fins a aquesta època, cada família havia menat la seva pròpia existència; la cronologia sembla indicar que el factor desencadenant d'aquesta reacció de defensa entre la cúpula nobiliària va ser el moderat increment de la participació política dels estaments intermedis, durant la capitania de Guglielmo Boccanegra.

${ }^{19}$ Els primers oficis a organitzar-se corporativament van ser els relacionats amb el comerç (traginers, corredors), la fabricació d'armes (escuders) i l'abastament alimentari de la ciutat (carnissers); totes aquestes profesions s'havien dotat de cònsols durant la primera meitat del segle XIII [J. HEERS, Gênes au XVe siècle, activité economique et problèmes sociaux, Paris, 1961 , p. 583, Y. RENOUARD-Ph. BRAUNSTEIN, Les villes d'Italie de la fin du X' siècle au début $d u$ XIV siècle, Paris, SEDES, I, 1969, .p. 245]. Durant el govern de Guglielmo Boccanegra, a la dècada central de la centúria, el moviment associatiu prospera considerablement, com conseqüència del decisiu suport ofert pels mercaders i pels menestrals al capità [R.S. LóPEZ, Studi sull'economia genovese, p. 150]. Els rams tèxtils i de la confecció no disposaran, tanmateix, de gestors propis fins al darrer quart del segle XIII: dos consules artis lanerie, assistits per catorze consellers, apareixen esmentats el 1274 [R.S. LóPEZ, Economia genovese p. 137]; algunes dècades després, el 1301, són els dos consules, el clavarius i els catorze consiliari artis et universitatis hominum textorum Ianue qui apareixen a la documentació, com també els dos consules de l'ars sartoriorum [G. CARO, Genova sul Mediterraneo, II, p. 326, nota 125$]$. 
governar conjuntament i el sistema de la doble capitania es col-lapsava, la coordinació de la República es confiava a un Capitano o a un Podestà estranger ${ }^{20}$, renovable anualment, les atribucions del qual havien estat minuciosament regulades ${ }^{21}$. El buit polític generat per l'absència dels dos capitans era omplert també per l'Abbas, el qual, malgrat que a l'organigrama administratiu ocupava un nivell inferior al del Podestà, pel fet de representar el Popolo i ser una persona del país, podia condicionar més eficaçment les decisions del Comú. La quantitat de qüestions sotmeses al Consell General i la seva complexa estructura interna hi retardaven l'adopció d'acords. Per tal d'agilitzar el funcionament de l'assemblea, es va decidir, des del 1301, que les qüestions més importants fossin instruïdes per comissions especials. Moltes d'aquestes comissions van gaudir d'atribucions àmplies, autònomes i de llarga durada. Entre aquests nous organismes delegats sobresurten: els Octo sapientes super raubarie, que s'encarregaven de sancionar els actes de violència comesos pels genovesos, de contenir la pirateria i de la restitució dels béns als damnificats; els Octo sapientes mercantie, a qui estava reservada la concesió de marques i represàlies, la supervisió del comerç exterior i el control de les autoritats de les colònies d'ultramar; i l'Officium assignationis mutuorum, amb atribucions damunt les emissions de deute públic, les compere, i els préstecs forçosos al Comú ${ }^{22}$.

Totes aquestes reformes polítiques, instaurades entre el 1299 i el 1305, van agilitar el funcionament del Comú, però no hi van introduir un repartiment equilibrat del poder polític entre els diversos estaments socials. Les grans famílies gibel-lines, des d'un segon pla, continuaven controlant la situació. Aquest monopoli esdevé encara més efectiu des del gener de 1306, quan, amb el concurs d'un sector majoritari de les capes populars, aconsegueixen reinstaurar -per tercera volta- el règim la doble capitania en les persones d'Opicino Spinola i Bernabò Doria, als quals confereixen unes atribucions molts àmplies ${ }^{23}$, uns poders que els dos electes transformaran de fet gairebé en absoluts. El control establert pels dos capitans sobre els

\footnotetext{
${ }^{20}$ Lanfranco de Suardi, Beltramo de Ficini i Simone de Gromello, ciutadans de Bèrgam, van presidir la República del 1291 al 1296. [I. DoRIA, Annales Ianuenses, pp. 124, 147 i 170]. Belloto di Calcho i Damiano di Osna, milanesos, Angelo di Pietramala, d'Arezzo, i Guglielmo di Castello, d'Asti, ho van fer entre 1299 i 1306 [G. STELLA, Annales Ianuenses, col. 1009].

${ }^{21}$ G. CARO, Genova sul Mediterraneo, II, pp. 155 i 303-305.

${ }^{22} \mathrm{G}$. CARO, Genova sul Mediterraneo, II, pp. 308- 315

${ }^{23} \mathrm{G}$. CARO, Genova sul Mediterraneo, II, pp.318-319.
} 
organismes de decisió del Comú es tan efectiu que els permetrà adoptar una política populista: si ja, abans, els Conestabili del Popolo participaven en les sessions del Consell General, des d'ara seran escoltats també a l'assemblea restringida dels Anciani, fins i tot en qüestions que no afecten solament el Popolo sinó també el Comúri

Les arti, fins a l'aparició dels dogui vitalicis, el 1339, són associacions estrictament professionals ${ }^{25}$, que no disposen de representants a les assemblees polítiques ni constitueixen un contrapès efectiu de l'aristocrà$\mathrm{cia}^{26}$. Els estaments intermedis, al primer terç del segle XIV, no governaven, doncs, a la capital lígur, sinó que tan sols hi arbitraven les rivalitats que periòdicament esclataven entre les faccions nobiliàries pel control del poder. Era lògic que un col-lectiu que controlava la terra, les finances i la milícia monopolitzés també el poder polític. L'estabilitat viscuda entre 1270 i 1310 - període en què la República assoleix el seu zenit econòmic i naval- és el resultat d'un equilibri transitori de forces, forjat per la noblesa gibel-lina, la qual, amb el suport d'un ampli sector de les capes intermèdies urbanes, neutralitza la facció aristocràtica güelfa i obre - menys efectivament que nominal- la gestió del Comú als mercaders i menestrals més qualificats i solvents. El sistema de la doble capitania gibel-lina va poder prolongar-se més de quatre dècades - un període llarg, si tenim en compte la durada mitjana dels governs a les ciutats-estats de la Itàlia septentrional- perquè era un reflex fidel de l'estructura social subjacent, basada en una burgesia mercantil i menestral que va anar adquirint una consciència de si mateixa, que la impel·lia a reclamar una participació en l'Administració pública, però que encara no era econòmicament prou forta ni jurídicament prou organitzada per a dirigir-la, i en una noblesa potent per l'exercici del comerç, l'armament naval i el crèdit, amb extensos patrimonis territorials, però dividida en dues faccions gairebé equilibrades, cada una de les quals necessitava el suport del poble per a imposar-se a l'altra ${ }^{27}$.

\footnotetext{
${ }^{24} \mathrm{G}$. CARO, Genova sul Mediterraneo, II, p. 325.

${ }^{25} \mathrm{Al}$ Consell General del 6 de novembre de 1307 hi van participar els "conestabuli et novi et etiam magna quantitas nobilium et aliorum popularium", pero no els "consules ministeriorum": G. CARO, Genova sul Mediterraneo, II, p. 326, nota 127.

${ }^{26} \mathrm{~J}$. HEERS, Gênes au $\mathrm{XV}$ siècle, pp. 251 i 583.

${ }^{27}$ V. VITALE, Breviario della Storia di Genova, I; p. 86. R. S. LÓPEZ, Storia delle colonie genovese nel Medio Evo, Bologna, Zanichelli, 1938, p. 226-227.
} 
Tots aquests canvis endisen les seves arrels en l'afany de les capes mitjanes urbanes d'incrementar la seva participació en la riquesa creada, durant el segle XIII, per l'auge del comerç i el desvetllament de la manufactura. No es tracta, doncs, de les seqüeles d'una contracció estructural de l'economia urbana, sinó de reaccions puntuals davant les inflexions de la conjuntura, de meres crisis de creixement.

Mentre que als moviments de masses dels segles XII i XIII - pastoureaux, càtars, valdesos, dolcinistes- els objectius polítics i socials no eren obertament expressats, ni tal volta conscientment sentits ${ }^{28}$, del 1300 ençà, els programes de les revoltes populars, especialment de les urbanes, esdeven més específics i les reivindicacions econòmiques, socials i polítiques eclipsen els plantejaments religiosos ${ }^{29}$.

Les monarquies, per damunt d'aquests conflictes rurals i urbans, procuren intensificar el control fiscal i judicial arreu de llurs respectius reialmes, tot suprimint-hi enclavaments immunes; malden per sotmetre a la seva autoritat els grans feudataris i les ciutat més riques, amb resultats diversos, positius a França, força més minsos a la Corona Catalanoaragonesa i a Castella.

\section{LES RELACIONS INTERNACIONALS}

A la Mediterrània coincideixen, al confins dels segles XIII i XIV, dues modalitats d'expansions ultramarines: les preponderantment mercantils (la genovesa i la veneciana) i les marcadament polítiques i militars (la catalana i l'angevina). Mentre que les primeres es conformen amb garantir als seus ciutadans un accés fiscalment privilegiat als mercats i una jurisdicció civil autònoma, personificada en els cònsols, no reclamen més territori que el necessari per a crear alfòndecs i pressuposen unes fortes concentracions de capital, una tecnologia mercantil evolucionada i, sobretot, un potencial naval capaç de garantir l'efectivitat de les concessions obtingudes a l'estranger; les segones, desenvolupades per estats amb unes estructures navals i mercantils quelcom menys desenvolupades, pel fet de no poder col·locar els

\footnotetext{
${ }^{28} \mathrm{R}$. HILTON, Siervos liberados. Los movimientos campesinos medievales y el levantamiento inglés de 1381, Madrid, Siglo Veintiuno, 1978, pp. 129-142.

${ }^{29}$ Ibidem, p. 142.
} 
seus homes de negoci al mateix pla que els concurrents més qualificats sense conquerir el territori, exigeixen, ultra flotes eficients, una participació important dels exèrcits feudals.

L'afany de totes les potències riberenques per a reforçar les seves posicions al Mare Nostrum generarà nombroses col-lisions: Gènova s'enfrontarà amb Pisa per la supremacia al Tirrè i pel control del port i de les salines de Càller, de gran valor estratègic i econòmic; la Corona Catalano-aragonesa disputarà a Nàpols el domini dels excedents frumentaris i dels ports de Sicília, situats a la confluència de les dues conques de la Mediterrània, a mig camí entre Catalunya i Palestina. En el decurs d'aquests enfrontaments, alguns emporis s'esfondraran (Pisa i Marsella) i uns altres pujaran (Gènova i Barcelona).

Durant aquests vint anys, els vells poders universals recularan, a la Mediterrània, davant els naixents estats territorials. La teocràcia pontifícia de Bonifaci VIII fracassarà davant la Monarquia francesa, que, sis anys després de l'afront d'Anagni (1303), atraurà la Santa Seu a Avinyó. El poder imperial d'Enric VII fracassarà, entre 1311 i 1313, davant la voluntat d'autonomia de les ciutats de la Itàlia septentrional.

\section{L'annexió de Sicília a la Corona Catalano-aragonesa no modifica} l'estatut aranzelari de què gaudien els genovesos a l'illa.

Trinàcria s'havia convertit, durant la segona meitat del segle XIII, en un important mercat d'aprovisionament de queviures per als genovesos. L'interès de la República per l'illa responia a diverses raons: als seus excedents frumentaris ${ }^{30}$ i d'altres queviures, a la seva demanda sostinguda

\footnotetext{
${ }^{30}$ Manfred de Suàbia havia autorizat els genovesos, el 1257, a extreure anualment dels districtes insulars i continentals del regne de Sícilia 20.000 quintars de blat, a instaurar cònsols amb jurisidicció civil i criminal sobre els propis ciutadans a les principals places i a no pagar-hi més que una part dels impostos vigents per als mercaders estrangers [Liber Iurium Reipublicae Genuensis, I, cols. 1293-1296. G. CARO, Genova sul Mediterraneo, I, pp. 53-56], concessions que van ser ratificades el $1259 \mathrm{i}$ el 1261 [Liber Iurium, I, cols. 1293-1296 i 1346-1349. P. LISCIANDRELLI, Trattati e negoziazioni politiche della Repubblica di Genova (958-1797). Regesti, Genova, Società Ligure di Storia Patria, 1960, p. 74, n. 354. G. CARO, Genova sul Mediterraneo, I, p. 100. G. JEHEL, Les Génois en Mediterranée, p. 76]. Alguns anys després, el 1269, Carles d'Anjou, per tal d'atreure la República lígur al seu bàndol, garanteix la llibertat d'exportació de gra als seus ciutadans a Sicília i Nàpols, i els confirma els altres avantatges que els van concedir els Suabis [ASG, Materie politiche, mazzo 5; ed. C. Imperiale di Sant'Angelo, "Annali Genovesi", IV, 1926, nota 3 a p. 115. P. LisCIANDRELLI, Trattati di Genova, p. 77, n. 364. G. CARO, Genova sul Mediterraneo, I, pp. 214-227. S. RUNCIMAN, I Vespri siciliani. Storia del mondo mediterraneo a la fine del XIII secolo, Milano, Rizzoli, 1976, p. 197. G.
} 
de draps i d'altres articles manufacturats i a la favorable posició del seus ports en relació amb les vies marítimes que connectaven la Ligúria amb Ifriqiya i els emporis de Llevant.

La ciutat de Gènova, amb una població de l'ordre dels 100.000 habitants i situada en una regió muntanyosa pobra, amb sòls de poca potència $\mathrm{i}$ forts pendents, on la tecnologia i les estructures agràries de l'època només eren capaces de garantir un abastament adient d'oli, vi, llegums i fusta per a la construcció naval, es veia obligada a buscar fora de la Ligúria, a ultramar, una bona part dels queviures bàsics que reclamava diàriament la seva creixent població. Provença, Sicília, Mallorca, Nàpols i Toscana es converteixen, durant el segle XIII, en els territoris on la República adquireix els articles agropecuaris que no pot obtenir al conta$d o^{31}$. Devers 1290 , la capital de la Ligúria, per a l'abastament quotidià de productes de primera necessitat, a les èpoques de normalitat, ja depenia més de l'eficaç funcionament de la flota i del comerç exterior que no pas del treball dels agricultors de les àrees rurals sotmeses al seu control directe. L'afany de lucre havia penetrat profundament en tots els estaments de la societat lígur, fins $i$ tot entre la clerecia ${ }^{32}$. Gènova, durant el tercer quart del segle XIII, s'havia transformat en un dels principals mercats internacionals, cap el qual fluien - en quantitats creixents- articles provinents de la totalitat del món conegut ${ }^{33}$. En cap altra part d'Occident es produïa aleshores, segons Jacques Heers ${ }^{34}$, una desvinculació econòmica tan palesa d'una gran ciutat del seu districte, incapaç d'atendre'n les creixents necessitats, ni una depèndencia tan forta de l'estructura econòmica de l'Estat i de la vida quotiana dels ciutadans del sector mercantil ${ }^{35}$. Es lògic, doncs,

JEHEL, Les Génois en Mediterranée, p. 85. T.O. DE NEGRI, Storia de Genova, pp. 339 i 410]. Els nombrosos protocols conservats a l'Archivio di Stato de Genova demostren que els lígurs van exercir intensament aquests drets d'exportació [G. JEHEL, Les Génois en Mediterranée, pp. 339 i 463].

${ }^{31} \mathrm{G}$ JEHEL, Les Génois en Mediterranée, pp. 339-342 i 463.

${ }^{32}$ R.S. LÓPEZ, El comercio de la Europa Medieval: el Sur, "Historia Económica de la Universidad de Cambridge", dir. J. Clapham i E. Power, II, Madrid, Revista de Derecho Privado, 1967, p. 381. Ph. JONES, La Storia economica. Della caduta dell'Impero Romano al secolo XIV, "Storia d'Italia", coor. R. Romano i C. Vivanti, II-2, Torino, Einaudi, 1974, pp. 1764-1767.

${ }^{33}$ Genua, mundi totius janua; cit. Ph. JONES, La Storia economica, p. 1712.

${ }^{34}$ Gênes au XV' siècle, pp. 500-501.

${ }^{35}$ Ianunesis, ergo mercator; cit. Ph. JONES, La Storia economica, p. 1764. 
que la política exterior desenvolupada per la República estigués fortament condicionada pels imperatius del gran comerç $\mathrm{i}$ fos molt sensible a les oscil-lacions de la conjuntura internacional. La penetració lígur a Sicília abans del Vespro està ben documentada: Bertramino de Mari, el 1278, hi comerciava amb Mallorca; Enrico de Mari, resident a Marsala, era almirall de Carles d'Anjou, el 1282; per aquesta mateixa època, Antonio Imperatore disposava d'una de les notaries de Messina ${ }^{36}$.

Els pisans, quan es produeix la conquesta catalana, també portaven més d'un segle operant a l'illa; com els lígurs estaven presents en els principals estrats de la població urbana i, en menor grau, a l'Administració pública. Els della Barba, el 1273, exportaven cereals de Trinàcria a Toscana; alguns membres de la família Gallo, a més de comerciar a l'illa, havien aconseguit ingressar al notariat local; entre els homes de negocis de Palerm figuraven, poc abans del Vespro, alguns descendents de velles nissagues ${ }^{\circ}$ pisanes, dels da Vico, dels Rusticiis, dels Aliata, dels dal Verde, que s'hi haurien instal-lat a l'etapa del domini suabi o angevíi ${ }^{37}$. Els comerç desenvolupat pels homes de negocis de Pisa pivota damunt els cereals, el formatge, el cotò, la llana i les pells ${ }^{38}$. La identitat d'interessos provocava una forta concurrència mercantil entre lígurs i toscans a Trinàcria, situació que es prolongarà després de la conquesta catalano-aragonesa.

La iniciativa ultramarina de Pere el Gran i Constança de Hohenstaufen va gaudir de la connivència d'un ampli sector del gibel-linisme italiàa ${ }^{39}$ i del concurs decidit tant dels exilats ${ }^{40}$ i dels col-lectius privilegiats

\footnotetext{
${ }^{36}$ M. SCARlata-L. SCIASCIA, Documenti sulla luogotenenza di Federigo d'Aragona, 12941295, Palermo, I.L.A. Palma, 1978, pp. 35.

${ }^{37}$ M. SCarlata-L. SCiascia, Documenti di Federigo d'Aragona, pp. 33-34.

${ }^{38}$ Ibidem, p. 34.

${ }^{39}$ Pere el Gran, un cop conquerida l'illa, per tal de neutralitzar la imminent rèplica del front franco-angeví-güelf, no dubta a sol.licitar el suport de la noblesa pisana com també de les faccions gibel.lines de Florència, Pistoia i Siena: I. CARINI, De rebus regni Sicilie, Palermo, 1882, doc. DCXLVIII, p. 591.

${ }^{40}$ Coordinats per Joan de Procida, Roger Llúria i Conrad Lancia, que van ser els primers beneficiats pel canvi de domini de Sicília, per tal que Pere el Gran els va confiar la direcció de la reforma de les estructures administratives illenques. Joan Procida va ser nomenat canceller del regne de Sicília, Roger de Llúria, almirall, i Conrad Lancia, mestre racional, càrrecs que implicaven amplis poders i fortes rendes: M. SCARLATA-L. SCIASCIA, Documenti di Federigo d'Aragona, pp. 11-14.
} 
urbans ${ }^{41}$ sículs com dels armadors i comerciants catalans, els quals havien inclòs, des de la quarta dècada del segle XIII almenys, els ports illencs en els seus periples ${ }^{42}$. Els homes de negocis i els transportistes de Barcelona i Mallorca es devien haver format, en el decurs de les seves escales, una idea força precisa dels avantatges mercantils que implicaria el domini de Trinàcria, una gran plataforma de avituallament a l'àrea de contacte d'ambdues conques de la Mediterrània i un bon mercat tant per a vendre esclaus, teixits flamencs, oli i paper com per a comprar cereals, cotó i pebre $^{43}$. Abans del Vespro, hi havia ja colònies de catalans si més no a Messina ${ }^{44}$ i a Palerm ${ }^{45}$. A la llum dels testimonis documentals localitzats, del 1980 ençà, per Rafael Conde i Carme Batlle ${ }^{46}$ als fons Sentmenat, de l'Arxiu de la Corona d'Aragó, i Diversorum C, de l'Arxiu Capitular de Barcelona, respectivament, resulta difícil continuar afirmant, com encara ho feia Mario del Treppo al 1972, que la conquesta militar i el control polític

\footnotetext{
${ }^{4 !}$ Des de la petita i mitjana noblesa als quadres de l'Administració local. Personatges com Bartolomeo de Neocastro, Alaimo de Lentini, Palmieri Abbate o Gualterio de Caltagirone van desenvolupar un paper decisiu en la gènesi de l'alçament antiangeví de Palerm, en la seva extensió a tota l'illa i en la guerra subsegüent: M. Scarlata-L. SCIASCIA, Documenti $d i$ Federigo d'Aragona, pp. 16-17.

${ }^{42} \mathrm{La}$ ruta Barcelona-Sicília es degué obrir durant la dècada de 1230-1240, tot just acabada la conquesta catalana de Mallorca, per tal com la primera comanda que ens ha arribat data de l'octubre de 1238 [J.M. MADURELl-A. GARCÍA, Comandas comerciales barcelonesas de la Baja Edad Media, Barcelona, Consejo Superior de Investigaciones Científicas-Colegio de Notarios, 1973, doc. 2, pp. 151-152]. Per aquestes mateixes dades, dos mercaders barcelonins, Bernat i Guillem de Banyeres, operaven ja a Reggio, tot just a l'altre costat de l'estret de Messina [C. BATLLE, Les relacions entre Barcelona $i$ Sicília a la segona meitat del segle XIII, "XI Congresso di Storia della Corona d'Aragona", 2, Palermo, 1983, p. 149]

${ }^{43}$ J.M. MADURELl-A. GARCÍA, Comandas comerciales barcelonesas, doc. 10, pp. 157-158, doc. 12 , pp. 159 , i doc. 23 , pp. 167.- J.P. CUVILLIER, Barcelone, Gênes et le commerce du blé de Sicile vers le milieu du XIII siècle, "Atti del I Congresso Storico Liguria-Catalogna", Bordighera, 1974, pp. 161-170. R. CONDE, Los Llull: una familia de la burguesía barcelonesa del siglo XIII", "XI Congresso di Storia della Corona d'Aragona", 2, Palermo, 1983, pp. 382 i 391-396. C. BATLLE, Les relacions entre Barcelona i Sicília, pp. 149, 151-152 i 165. D. ABULAFIA, Sul commercio del grano siciliano nel tardo duecento, "XI Congresso di Storia della Corona d'Aragona", p. 11.

${ }^{44}$ On tenim documentada la presència, al tercer quart del segle, d'un considerable conjunt de mercaders, integrat per Julià Mercer, Pere Berenguer, Pere de Roses, Bernat de Caldes, Pere Giner, Guillem Roset, Arnau de Cors, Bernat Bonet, Guillem Sarriera, Bernat Palmenter, Pere de Lorida, Guillem d'Oda i Jaume Martí: C. BATLLE, Les relacions entre Barcelona i Sicília, pp. $156-159$.

${ }^{45}$ On operaven, les dècades anteriors a l'alçament antiangeví, Berenguer Satria, Bartomeu Despuig i Ponç de Vilanova: C. BATLle, Les relacions entre Barcelona i Sicilia, p. 158.

${ }^{46}$ Vegeu supra, nota 43.
} 
del territori van obrir als catalans els mercats de Sicília ${ }^{47}$. La seva activitat comercial i financera, sense assolir les cotes de la lígur o de la toscana ${ }^{48}$, ja hi era considerable des de l'època de Manfred de Suàbia.

El sobirà va considerar la conquesta de Sicília com una empresa pròpia i va organitzar l'explotació del nou mercat en profit de la Corona ${ }^{49}$, de l'exèrcit feudal d'ocupació ${ }^{50}$, dels oficials de la nova Administraciós ${ }^{51}$ i dels armadors catalans, que haurien de garantir les comunicacions entre les riberes ibèriques i sícules ${ }^{52}$. La precarietat inicial del seu domini i l'afany d'evitar una caiguda dels ingressos aranzelaris expliquen que el sobirà confirmés, el 24 de novembre de 1284, als genovesos - tres mesos després de la seva victòria damunt els pisans a la Melòria- el favorable estatut mercantil ${ }^{53}$ de què gaudien a l'illa des del regnat de Manfred $^{54}$ i que no

\footnotetext{
47" Prima del Vespro le attività mercantili dei catalani nell'isola erano pressoché inesistenti, e no per colpa della documentazione scarsa, quale pur ci informa delle iniziative dei catalan come armatori e come pirati lungo le rotte siciliane" [I mercanti catalani e l'espansione della Corona d'Aragona nel secolo XV, Napoli, L'Arte Tipografica, 1972, p. 149].

${ }^{48}$ Ben analitzada recentment per G. PeTraglia, I Toscani in Sicilia tra Due e Trecento: la penetrazione sociale e il radicamento dei ceti urbani, "Commercio, finanza, funzione pubblica. Stranieri in Sicilia e in Sardegna nei secoli XIII-XV", Napoli, Liguori, 1989, pp. 129-218.

${ }^{49} \mathrm{Generalitzant} \mathrm{els} \mathrm{impostos} \mathrm{que} \mathrm{gravaven} \mathrm{les} \mathrm{tretes} \mathrm{de} \mathrm{cereals,} \mathrm{creats} \mathrm{per} \mathrm{Frederic} \mathrm{II.} \mathrm{Les}$ exportacions de gra, estretament controlades pels nous funcionaris reials, estaven sotmeses a un ius exiture, que recaptava el Mestre Portulà, i a un ius dohane, el cobrament del qual corresponia als agents de duanes. El rendiment net d'aquestes entrades va ser xifrat, als pocs mesos de l'establiment de la Administració catalana a l'illa, en 2.000 unces [I CARINI, Gli Archivi e le Biblioteche di Spagna in rapporto alla storia d'Italia in generale e di Sicilia in particolare, Palermo, II, 1897, doc. CCCCLXVII, p. 433]. La quantia d'ambdues taxes, inicialment no precisada, es va anar concretant durant la primera fase del regnat de Jaume d'Aragó: al 1293, era de 3 i 1 tarí, respectivament [ACA, C, reg. 261, fols. 98 r.-98 v.; ed F. Giunta-N. Giordano-M. SCARlata-L. Sciascia, Acta siculo-aragonensia, I-1, Palermo, 1972, doc. 120, p. 104. M. SCARlata-L. SCIASCIA, Documenti di Federigo d'Aragona, p. 30 C. Trasselli, Genovesi in Sicilia, "Atti della Società Ligure di Storia Patria", IX (Genova, 1969), p. 160].

${ }^{50}$ Els caps del qual van rebre castells, terres i càrrecs a l'illa; entre els primers beneficiaris figuren Pere de Queralt, Beltran de Bellpuig, Bernat de Sarrià, Hug Tallac, Guillem Galceran de Cartellà, Gerard de Torres i Blasco de Alagón: M. Scarlata-L. SCIASCIA, Documenti di Federigo d'Aragona, pp. 11-12, 19, 22, 24.

${ }^{51}$ Com el vicecanceller Ramon de Manresa, el tresorer Cervià Riera, el gusticiere de Castrogiovanni, Demone e Milazzo Guillem de Montagut o el maestro giusticiere Ramon Alemany: Ibidem, pp. 12, 19, 23, 26

${ }^{52} \mathrm{M}$. DEL TREPPO, I mercanti catalani, p. 150.

${ }^{53}$ Els eixos fonamentals del qual consistien en la llibertat de comerç, les reduccions aranzelàries, l'establiment de consolats i la no-aplicació als vaixells i a les mercaderies lígurs del dret de naufragi. Aquests avantatges, ratificats per Carles d'Anjou al tractat de 1269 [ Vegeu, supra, nota 30], van ser confirmats a l'acord del 1276 [Liber Iurium Reipublicae Genuensis, I, p. 1429-1431; G. CARO, Genova sul Mediterraneo, I, pp. 354-366].
} 
hi concedís, en canvi, cap privilegi comercial als homes de negocis catalans $^{55}$. Per als dissenyadors de la política exterior de Pere el Gran, el suport de les ciutats marítimes de la "Confederació" a una empresa que reforçava la seva presència en ambdues conques de la Mediterrània estava garantida; la neutralitat lígur, en canvi, no es podia donar, malgrat l'ascripció dels seus governants al bàndol gibel-lí, per descomptada, pressuposava unes compensacions adients. El fet que, el prop passat mes de juny de 1284, una flota de trenta galeres, confiada pel Comú a Benedetto Zaccaria, hagués capturat, al golf de Càller, una nau veneciana i una altra de catalana ${ }^{56}$, palesava que Gènova, malgrat l'enfrontament obert que mantenia amb Pisa, seguia de prop la guerra del Vespro sicilià, per tal de vendre a bon preu a ambdòs contendents la seva no-intervenció. Contestar la captura d'un vaixell valorat en $4.96011^{57}$ amb una concessió aranzelària i no pas amb una sol-licitud de rescabalament o una represàlia només és concebible si l'atacant disposa d'un potencial naval capaç de fer sentir la seva influència arreu de la Mediterrània i si el sobirà de l'atacat, immergit en un conflicte de vastes proporcions, considera que no podria resistir el decantament de l'agressor pel bàndol rival. Els interessos de la Corona podien, a curt o mitjà termini, no coincidir plenament amb els dels mercaders catalans. Malgrat aquest $\mathrm{i}$ algun altre incident, el comte-rei va reservar alguns càrrecs de la nova Administració per als genovesos: Antonio Imperatore conserva la seva notaria a Messina i un parent seu, Goffredo, hi és nombrat jutge ${ }^{58}$.

La iniciativa contemporitzadora del comte-rei van produir l'efecte esperat: el Comú es va mantenir al marge de la contesa i no va impedir als seus súbdits més audaços de posar-se al servei d'ambdós bàndols; així, mentre Enrico de Mari participa, com a almirall de la flota franco-napolitana, en la batalla de les illes Formigues ${ }^{59}$, Francesco Squarciafico, a les

\footnotetext{
${ }^{54} \mathrm{G}$. CARO, Genova sul Mediterraneo, II, pp. 54-57.

${ }^{55} \mathrm{M}$. DEL TREPPO, I mercanti catalani, p. 150. p. 51 .

${ }^{56}$ I. DorIA, Annales Ianuenses. Anni MCCLXXX-MCCLXXXIII, "Annali Genovesi", V, 1929,

${ }^{57}$ Ibidem.

${ }^{58}$ M. Scarlata-L. Sciascia, Documenti di Federigo d'Aragona, pp. 35.

${ }^{59}$ R. MUnTANER, Crònica, "Les quatre grans cròniques", ed. F. Soldevila, Barcelona, Selecta, 1971, p. 796. J. ZURITA, Anales de la Corona de Aragón, IV, LXVIII, ed. A. Canellas, II, Zaragoza, CSIC, 1970, p. 243. G. CARO, Genova sul Mediterraneo, II, p. 56.
} 
ordres de Roger de Llúria, hi contribueix al triomf de l'armada catalana ${ }^{60}$, i el mercader Niverino transporta blat $i$ ordi per compte del comte-rei ${ }^{61}$. Aquest plantejament de la Diarquia gibel-lina era el més rendible per a la República lígur, per tal com li permetía conjurar l'hostilitat oberta de la Santa Seu i de França ${ }^{62}$, garantir als seus ciutadans el lliure accés als mercats napolitans i provençals, concentrar els seus efectius en la pugna contra Pisa per la supremacia a la mar Tirrena ${ }^{63}$, interceptar sistemàticament $-\mathrm{i}$ sense costos importants ${ }^{64}$ - els vaixells catalans que es dirigissin cap a les boques de l'Arno i preservar les importacions directes de blat sicilià ${ }^{65}$.

Pere el Gran va concedir també una atenció particular a tots els toscats, no sols als pisans, tant per a assegurar-se'n la col·laboració com pel volum d'operacions comercials i financeres que desemvolupaven als mercats illencs. Las famílies pisanes ja instal lades o que s'establiren Sicília arran de la conquesta catalana van gaudir de la confiança del comte-rei i dels seus col-laboradors immediats: Diogini della Barba va obtenir, el 1282, el càrrec de governador de Malta i Gozzo; per les mateixes dates, Corrallo da Vico regia l'alfòndec sicilià a Tunis i Raineri di Corrado actuava com a cònsol dels pisans a Palerm ${ }^{66}$. Amb motiu d'un enfrontament entre pisans i genovesos a la capital illenca, el sobirà ordena, el 21 de novembre, als oficials locals que fassin retorar les mercaderies robades als toscans i els garenteixen la integritat personal i econòmica ${ }^{67}$. Un mesos després, el gener de 1283, dues galeres genoveses ataquen una nau pisana al port de Tràpani.

\footnotetext{
${ }^{60} \mathrm{G}$. CARO, Genova sul Mediterraneo, II, p. 56

${ }^{61}$ I. CARINI, De rebus regni Sicilie, doc. 602, p. 546.

${ }^{62} \mathrm{G}$. CARO, Genova sul Mediterraneo, II, pp. 55-56.

${ }^{63} \mathrm{G}$. CARO, Genova sul Mediterraneo, II, pp. 9-46 y 72-101

${ }^{64}$ Sense provocar, en cada cas, una resposta puntual i equiparable de la poderosa flota del comte-rei.

${ }^{65}$ Els homes de negocis lígurs no van interrompre les seves compres de cereals als ports sicilians en cap de les diverses etapes de la llarga guerra del Vespro: D. ABulafia, Sul commercio del grano siciliano, pp. 10-11; vegeu també infra, pp. 755 i 770 .

${ }^{66} \mathrm{M}$. SCARLATA-L. SCIASCia, Documenti di Federigo d'Aragona, p. 34

67"Volumus et fidelitate vestre precipiendo mandamus firmiter et expresse quatenus singulis pisanis eisdem fidelibus nostris in eundo, morando vel reddendo per partes ipsas impedimentum aliquod vel molestiam nullatenus inferatis nec inferi per aliquem permitatis, quin immo ipsos morari, transire et degere in insula nostra Sicilie, cum aliis nostris fidelibus, secure et paciffice": ACA, reg. 53, fols 39 v.-40 r.; ed. I. CARINI, De rebus regni Sicilie, doc. 126, pp. 116-117.
} 
El monarca, per tal d'evitar que Trinàcria esdevinga un dels escenaris de la pugna que mantenen les dues Repúbliques marineres, ordena al jutge de $\mathrm{Val}$ de Mazzara que exigeixi a les tripulacions dels dos vaixells lígurs una caució que aquest tipus de fet no es repetiran a aigües sícula, on genovesos i pisans hauran de concorre pacíficament ${ }^{68}$. El projectes de concòrdia de Pere el Gran topen tanmeteix amb la hostilitat recíproca de les dues colònies de la Itàlia septentrional, el 7 de maig, ha de suggerir a la reina Constança que rellevi del càrrec de jutge de Val de Mazzara al pisà Girardo Bocci, per tal que amb la seva actuació lesionava sistemàticament els interessos dels ciutadans genovesos que mercadejaven a aquesta circumscripció ${ }^{69}$.

2. Génova, per tal de tallar les exportacions de forment sicilià a Pisa, desencadena una guerra de cors contra les embarcacions catalanes

La intensitat del contenciós toscà-lígur per la supremacia naval al Tirrè i la inestabilitat introduida, el 1282, al mezzogiorno italià per la conquesta catalana de Sicília repercuteixen negativament en la seguretat de la navegació a la conca occidental de la Mediterrània. Els contendents no distingeixen amb precisió, en el decurs dels atacs recíprocs, els enemics dels neutrals. Durant l'estiu de 1283, una esquadra pisana penetra al port castellà d'Alacant i hi captura una nau i dos llenys genovesos ${ }^{70}$; per aquesta mateixa època, una altra nau lígur, de la qual era patró Ugolino Baioni Spinola, noliejada per mallorquins, es interceptada, en aigües del sultanat de Granada, per una esquadra pisana de dues galeres i una nau, conduida per Bindo Bufaco, i desviada cap a Càller ${ }^{71}$. Els atacs pisans contra vaixells de la "confederció" es prolongaràn pràcticament fins a la derrota de la Melòria, a l'agost de 1284: una esquadra integrada per vuit llenys, amb Matteo Pascio al capdavant, ataca - infructuosament - a Bugia la nau del mallorquí Nicolau Matalaf i la persegueix fins al port de la capital balear; de retorn a Sardenya, al canal de Cabrera, aborda la tarida de Pere Bertòs, illenc, que venia de

\footnotetext{
${ }^{68} \mathrm{ACA}, \mathrm{C}$, reg. 53, fols 134 v.-135 r., ed. I. CARINI, De rebus regni Sicilie, docs. 415-416, pp. 306-307.

${ }^{69} \mathrm{ACA}, \mathrm{C}$, reg. 46, fol. $192 \mathrm{r}$.

${ }^{70} \mathrm{ACA}, \mathrm{C}$, reg, 46, fol. $123 \mathrm{v}$

${ }^{71}$ Iacopo DoRIA, Annales Ianuenses, pp. 40-41.
} 
Gènova, i se l'emporta cap a Càller ${ }^{72}$. Els reiterats incidesnt obliguen Pere el Gran a exigir al giudice Marià d'Arborea que obligui als pisans de Càller a restituir les mercaderies que han robat als seus súbdits ${ }^{73}$.

La situació va experimentar un capgirament total durant l'estiu de 1284, quan Gènova, a la Melòria, destrueix la major part de la flota pisana, en captura una bona part de les tripulacions i redueix la República de les boques de l'Arno a la condició de potència naval de segon ordre ${ }^{74}$. La metròpoli toscana, bloquejada navalment pels lígurs, obligada a consignar les restes de la seva marina a la defensa de les aigües immediates a Porto Pisano, degradada la infrastructura portuària, havia esdevingut un mercat deficitari de nòlits ${ }^{75}$. Els armadors catalans, com els venecians, es van apressar a atendre la demanda de mitjans de transport de la plaça toscana, on disposaven de cònsol des del $1277^{76}$. Una part considerable de les mercaderies i dels comerciants pisans, del 1285 ençà, viatgen en embarcacions catalanes i sícules ${ }^{77}$. L'adscripció política d'ambdós "Executius" al bàndol gibel·lí afavoria aquest acostament, que, com és lògic, suscitava recels a Gènova. Els incidents navals entre esquadres lígurs i vaixells de la Corona Catalano-aragonesa al Tirrè esclaten pocs mesos abans de la mort de Pere el Gran. Les concessions efectuades pel comte-rei als ciutadans del Comú a Sicília han privat, doncs, els napolitans de la col-laboració de la poderosa flota genovesa però no han obert, tanmateix, als navilis de la "Confederació" les àrees tancades pels lígurs. A mitjan primavera del 1285, Enrico Spinola, al capdavant d'una esquadra de cinc galeres i una sagetia de cinquanta-dos rems, captura, entre Còrcega i Capraia, una nau catalana que,

\footnotetext{
${ }^{72}$ ACA, C, reg. 46, fols. 188 v.-189 r. I. DoRIA, Annales Ianuenses, pp. 45.

${ }^{73}$ G. La Mantia, Codice Diplomatico dei re aragonesi di Sicilia Petro I, Giacomo, Federico II, Pietro II e Ludovico. Dalla rivoluzione siciliana del 1282 sino al 1355. I: Anni 1282-1290, Palermo, Scuola tip. "Boccone del Povero", 1917, doc. 44, p. 98.

${ }^{74} \mathrm{La}$ victòria lígur va impressionar la cronística coetània [I. DOR!A, Annales Ianuenses, pp. 54-57. G. VILlANI, Cronica, ed. F. Gherardi Dragomani, Frankfurt, Minerva GMBH, Unverränderter Nacdruck, 1969, I, pp. 423-424. Annali Placentini Gibellini, "Monumenta Germaniae Historica, Scriptores", XVIII, p. 578] i la historiografia decimonòmica [G. CARO, Genova e la supremazia sul Mediterraneo, II, pp, 38-46].

${ }^{75} \mathrm{M}$. TAngheroni, Politica, commercio, agricoltura a Pisa nel trecento, Pisa, Paccini, 1973, p. 77.

${ }^{76}$ ACA, C, reg. 39, fol 212 r.; cit. R. SÁINZ DE LA MAZA, Il consolato dei Catalani a Pisa durante il regno di Giacomo II d"Aragona. Notizie e documenti, "Medioevo. Saggi e Rassegne", 20 (Cagliari, 1996), p. 196, nota 4.

${ }^{77} \mathrm{G}$. CARO, Genova sul Mediterraneo, II, p. 76-77.
} 
provinent de Tunis, transportava llana i altres mercaderies berbers cap a Porto Pisano i una nau de Palerm que, carregada de carn i formatge sicilians, es dirigia també cap a la plaça del baix $\mathrm{Arno}^{78}$. Una altra flotilla lígur, integrada per cinc galeres de Portovenere, el patró de la qual era el mateix Enrico Spinola, intercepta, el novembre, una nau siciliana amb un carregament de cereals, quan iniciava la penetració a Porto Pisano, i la desvia cap a Gènova ${ }^{79}$.

A la mort de Pere el Gran, el 10 de novembre de 1285, el seu secundogènit, l'infant Jaume, és coronat rei de Sicília. L'atenuació dels vincles polítics entre Catalunya i Trinàcria és contrarestada, tanmateix, amb la confirmació en els seus càrrecs dels oficials ibèrics i el reforçament de les relacions econòmiques. El 18 de febrer de 1286, el nou sobirà, tot just assumit el poder, autoritza els catalans a extreure cereals de l'illa per a l'abastament del mercat interior del Principat ${ }^{80}$. Uns quants dies després, el 22 de febrer, els reconeix el dret d'establir-hi consolats $^{81}$ i declara inaplicable als seus vaixells, carregaments i béns el ius naufragii ${ }^{82}$. Els mercaders barcelonins, el 17 de juliol de 1288, obtenen, a més, de la cort de Palerm que els estengui l'estatut mercantil i fiscal de nació més afavori$\mathrm{da}^{83}$ que acabava de confirmar als genovesos ${ }^{84}$. Aquesta línia d'actuació obeïa a la necessitat del monarca d'involucrar les grans ciutats catalanes en la defensa de l'illa davant la coalició franco-angevina. La consolidació d'una

${ }^{78}$ I. DoRIA, Annales Ianuenses, p. 62. G. CARO, Genova sul Mediterraneo, II, pp. 79-80.

${ }^{79}$ I. DORIA, Annales Ianuenses, p. 67.

${ }^{80}$ IMHB, Llibre Vert, I, fols. 268-270; ed. C. BATLle a A. de CAPMANY, Memorias históricas sobre la marina, comercio y artes de la antigua ciudad de Barcelona, $2^{\mathrm{a}}$, Barcelona, Cámara Oficial de Comercio y Navegación, 1962, II-1, doc. 57, p. 87.

${ }^{81}$ Els titulars dels quals podran jutjar les causes civils plantejades entre els mercaders catalans en territori sicilià, les criminals les continuaran instruint i fallant els tribunals locals: IMHB, Llibre Vert, I, fol. 251; ed. C. BATLLE en A. de CAPMANY, Memorias històricas de Barcelona, doc. 40, p. 63.

${ }^{82} \mathrm{IMHB}$, Llibre Vert, I, fol. 251; ed. C. BATLle a A. de CAPMANY, Memorias históricas de Barcelona, II-1, doc. 40 , p. 63

${ }^{83} \mathrm{IMHB}$, Llibre Vermell, II, fols. 134 v.-135 v.; ed. C. BatLle a A. DE CAPMANY, Memorias históricas de Barcelona, II-1, doc. 42, pp. 65-66

${ }^{84} \mathrm{El} 21$ de març de 1286 [Archivio di Stato di Genova, Governo, Segreto, Materie Potiche, 6/2725, 47 bis; ed. P. LISCIANDRELLI, Trattati di Genova, p. 90, n. 430]. L'equiparació fiscal dels mercaders de la capital catalana al ciutadans de la metròpoli lígur continuava vigent, a les ciutats portuàries sicilianes, vers el 1340, quan F.B. PEGOLOTTI va redactar La pratica della mercatura [ed. A. Evans, Cambridge Mass., The Mediaeval Academy of America, 1936, p. 111]. 
branca col-lateral del casal de Barcelona a Sicilía, com a conseqüència de l'hostilitat que suscitava entre els güelfs i a la Santa Seu, no estava garantida amb els efectius navals i financers locals ${ }^{85}$, sinó que depenia també de què el cap de la dinastia, Alfons el Liberal, i un ampli sector dels seus súbdits n'identifiquessin la pervivència amb la defensa dels propis interessos. La reconquesta de l'archipèlag balear, a la darreria del 1285, per la Corona d'Aragó, com a represàlia per la col-laboració oberta de Jaume II de Mallorca amb la coalició franco-angevina ${ }^{86}$, refermava paral-lelament la col·laboració entre catalans i illencs a ultramar ${ }^{87}$ i rebaixava les cotes de risc dels seus respectius periples navals per la conca occidental del Mare Nostrum $^{88}$.

Els efectes de les concessions mercantils i fiscals no es van fer esperar: el tràfic entre els ports ibèrics i sículs de la Corona d'Aragó va experimentar, en pocs anys, un creixement important. L'activitat comercial dels catalans, que durant el domini suabi i angeví s'havia orientat preferentment cap a Messina, va tendir a concentrar-se al sector occidental de l'illa ${ }^{89}$, el més accessible des de Barcelona, i esdevé, del 1300 ençà, un important factor extern de desenvolupament per a la plaça de Trapani ${ }^{90}$. Els homes de negocis de Catalunya, Mallorca i València, a la darreria del segle XIII, continuaven venent a Trinàcria draps nòrdics ${ }^{91}$, safrà, oli i paper ${ }^{92}$,

\footnotetext{
${ }^{85} \mathrm{La}$ fidelitat dels quals havia estat comprada amb càrrecs. Els nous "gestors" catalans, amb la redistribució intel.ligent dels oficis, havien aconseguit una successió indolora dels governants precedents, havien captat les classes dirigents $\mathrm{i}$ havien preservat inalterada l'estructura de la societat siciliana.

${ }^{86}$ R. MUNTANER, Crònica, "Les quatre grans cròniques", p. 808. I. DoRIA, Annales Ianuenses, pp. 69-70 i 81. J. ZurITA, Anales de la Corona de Aragón, II, pp. 264-266. M. FERrER, La Conquista de Mallorca por Alfonso III, "Boletín de la Sociedad Arqueològica Luliana", XXX (Palma de Mallorca, 1947-1952), pp. 274-288. A. RIERA MELIS, La Corona de Aragón y el Reino de Mallorca en el primer cuarto del siglo XIV. 1: Las repercusiones arancelarias de la autonomía balear (1298-1311), Madrid-Barcelona, CSIC, 1986, pp. 33, 6072; IDEM, El Regne de Mallorca en el context internacional de la primera meitat del segle XIV, "Homenatge a la memòria del professor Dr. Emilio Sáez", Barcelona, 1989, pp. 54 i 55.

${ }^{87}$ A. Riera Melis, La Corona de Aragón y el Reino de Mallorca, p. 71.

${ }^{88} \mathrm{La}$ importància estratègica dels ports balears per a la consolidació del domini català a Sicília queda clarament reflectida en la frase que els cronista coetani Ramon Muntaner posa en boca de Roger de Llúria al moment que Pere el Gran li exposa el projecte de conquerir les Illes: "Senyor, molt savi pensament havets feit,... E dic-vos que aquesta cosa que a mi fa paor d'aquesta guerra és que la illa de Mallorca no fos contra nos" [Crònica, p. 801].

${ }^{89}$ Vegeu infra, notes 95 i 99.

${ }^{90}$ M. DEL TREPPO, I mercanti catalani, pp. 151-152.

${ }^{91}$ J.M. Madurell-A. García, Comandas barcelonesas, doc. 55, pp. 195-196.
} 
i hi seguien comprant blat i cotó ${ }^{93}$. Aquesta relació d'intercanvis es mantindrà durant tota la Baixa Edat Mitjana, amb les úniques variants de la substitució progressiva de les teles nòrdiques pels "draps de la terra" i l'aparició del sucre i la seda entre les importacions catalanes provinents de l'illa ${ }^{94}$.

Els negocis adquiriren prest una regularitat tal que un nombre creixent de mercaders i d'armadors catalans ${ }^{95}$, mallorquins ${ }^{96}$ i valencians $^{97}$ va optar per instal-lar-se a les principals places sícules, on ben prest hi van disposar de consolat. Ja el 1286, Jaume d'Aragó havia prohibit a un

${ }^{92}$ J.M. MAdURELL-A. GARCíA, Comandas comerciales barcelonesas, doc. 58, pp. 197-198.

${ }^{93}$ J.M. MADURELL-A. GARCÍA, Comandas comerciales barcelonesas, doc. 37, pp. 179-180, doc. 55, pp. 195-196. P. BugARELLA, Le imbreviature del notaio Adamo de Citella a Palermo (1 ${ }^{\circ}$ Registro: $\left.1286-1287\right)$, Roma, Centro di ricerca pergamene medievali e Protocolli notarili, 1981, doc. 245, p. 151. D. ABULAFIA, Sul commercio del grano siciliano, pp. 11-12.

${ }^{94} \mathrm{M}$. DEL TREPPO, I mercanti catalani, p. 165. C. CARRÈRE, Barcelone, centre économique à l'èpoque des difficultés, 1380-1462, II, Paris-La Haye, Mouton \& Co., 1967, pp. 636-637. $\mathrm{H}$. BRESC, La draperie catalane au mirorir sicilien, 1300-1460, "Acta Historica et Archaeologica Mediaevalia", 4 (Barcelona, 1983), pp. 107-127. A. RIERA MELIS-G. FELIU, Les activitats econòmiques a la Baixa Edat Mitjana, "Història de Barcelona", dir. Jaume Sobrequés, Barcelona, Ajuntament-Enciclopèdia Catalana, 3, 1992, pp. 199-202.

${ }^{95}$ Com Domènec Oriol, Berenguer Vilafresser, Guillem de Santa Coloma, Pere Corbella, Arnau Panides, Bernat de Sant Emeteri, Pericó d'Anglesola, Bernat Sunyer, Pere de Vallllebrera, Huguet de Cambrils, Guillem Albert, Guillem de Gallifa, Bernat Boscà, Pere Salcet, Pere Vilà, Pere Santilla, Guillem Robí, Domenec Caçador, Jaume Corretger, Bernat Segalar, Ramon Borrassà, Pere de Montmeló, Jaume de Piera, Guillem de Caldes, Guillem de Solar, Pere de Girona, Bernat Galcerà, Pere de Banyeres, Bernat d'Esplugues, Bernat Segarra, Bernat Martí, Romeu de Coromines, Pere Carbó, Jaume Riba, Bernat Pasqual, Jaume Dalmau, Guillem Carbó, Guillem de Casanova, Pericó Figarola, Guillem de Cerdanyola, Guillem Fava, Pere de Bardoll, Jaume de Cànoves, Berenguer Roig, Simó de Pruners, Romeu Serra, Guillem d'Horta, Guillem de Llossa, Ramon de Bell-lloc, Pere Ferrer, Jaume Andreu, Jaume Rossell, Bernat d'Odena, Pere Marí, Bernat de Sant Feliu, Guillem d'Ortí, Berenguer de Sarrià, Pere Vidal, Bernat de Feu, que operaven a Palerm [P. BUgarella, Le imbreviature del notaio Adamo de Citella, doc. 13 , p. 24 , doc. 65 , p. 54 , doc. 105 , pp. $76-77$, doc. 117 , p. 84 , doc. 211 , p. 132 , doc. 245 , p. 151 , doc. 252 , p. 155 , doc. 258 , p. 158 , doc. 260 , p. 159 , doc. 267 , p. 164 , doc. 268 , p. 164 , doc. 169 , p. 165 , doc. 280 , p. 170 , doc. 284 , p. 173 , doc. 286 , p. 174 , doc. 287 p. 174 , doc. 291 , p. 177 , doc. 292 , p. 177 , doc. 296 , p. 180 , doc. 300 , p. 182 , doc. 304 , p. 185 , doc. 306 , pp. $186-187$, doc. 314 , p. 191 , doc. 316 , p. 192 , doc. 328 , p. 199 , doc. 338 , pp. $204-205$, doc. 347, p. 210 , doc. 355 , p. 214 , doc. 392 , p. 234], Jaume Dierga i Pere de Parer, instal.lats a Messina, Bernat Marquet, ciutadà de Siracusa, Ramon de Tolosa, Francesc de Granollers i Guillem de Peralta, veïns de Trapani [C. BATLLE, Les relacions entre Barcelona i Sicília, pp. pp. 155-156 i 159-161. M. Scarlata-L. SCIASCIA, Documenti di Federigo d'Aragona, p. 26]

${ }^{96}$ Com Ramon de Castelló, Joan Vives, Arnau de Quadres i Ramon Ses Moles [P. Bugarella, Le imbreviature del notaio Adamo de Citella, doc. 5, p. 21, doc. 105, pp. 76-77, doc. 248 , p. 152 , doc. 373 , p. 223]

${ }^{97}$ Com Bernat Caçà i Pere Garriga [P. Bugarella, Imbreviature del notaio Adamo de Citella, doc. 27, p. 34] 
particular de Messina edificar una casa davant la llotja dels catalans ${ }^{98}$; Bernat Tripò i Berenguer Bris, l'any següent, actuaven com a cònsols de catalans a Palerm i Trapani, respectivament ${ }^{99}$. Des dels estratègics ports sicilians, les embarcacions i els comerciants de la Corona Catalano-aragonesa intensifiquen la seva presència als grans mercats internacionals de la Mediterrània oriental, sense que la seva presència, encara poc consolidada, susciti recels importants entre les potències navals més ben instal-lades a l'àrea: Benedetto Zaccaria, el novembre, 1286, envia un carregament d'alum de Focea a Ligúria en una nau catalana. Aquesta primerenca col-laboració no es tancarà, emperò, amb saldo positiu, per tal com l'embarcació, desviada per una tempesta cap a Porto Pisano, no arribarà a la destinació ${ }^{100}$.

Els barcelonins, un cop equiparats fiscalment als lígurs, que continuaven comprant blat ${ }^{101} \mathrm{i}$ altres viandes ${ }^{102}$ a l'illa, intenten incrementar la participació en les lucratives exportacions de cereals sicilians cap a les grans ciutats de la Itàlia septentrional ${ }^{103}$. La col·laboració catalanogenovesa a l'Egeu no tindrà, emperò, equivalent al Tirrè, on algunes embarcacions de la "Confederació", amb l'excusa que transporten mercaderies propietat de pisans, seran interceptades per esquadres lígurs: el juliol de 1287, Franceschino de Porcello, al capdavant d'una galera i un galió armats pel Comú per a custodiar la Ribera de Llevant, penetra, a la recerca d'un lleny pisà, al golf de Fréjus, on, a més de cremar l'embarcació toscana, captura una barca catalana ${ }^{104}$. Aquest fet palesa que, en més d'una ocasió, les flotilles lígurs capturen vaixells de la "Confederació" en què no viatgen

\footnotetext{
${ }^{98}$ G. LA MANTIA, Codice diplomatico dei re aragonesi di Sicilia, doc. 149, p. 323.

${ }^{99} \mathrm{P}$. Bugarella, Le imbreviature del notaio Adamo de Citella, doc. 211, p. 210. C. BATLLE, Les relacions entre Barcelona i Sicília, p. 159. 35 .

${ }^{100}$ I. DORIA, Annales Ianuenses, p. 75. G. CARO, Genova sul Mediterraneo, II, p. 80, nota

${ }^{101} \mathrm{Com}$ ha quedat reflectit al primer dels pocs protocols notarials sicilians del segle XIII que ens han arribat, el del palermità Adamo de Citella, corresponent al bienni 1286-1287. L'11 d'abril de 1287, Arnaldo Marabotto, mercader genovès, compra a Pietro de Lando y Matteo Manganario, veïns de Girgenti, la considerable quantitat de 1050 salmes de blat, per 227 1/2 unces, és a dir, al preu, relativament alt, de $61 / 2$ tarins la salma: P. BuGARELla, Le imbreviature del notaio Adamo de Citella, doc. 233, p. 144.

${ }^{102}$ Guglielmo de Giordano, palermità, el 18 d'abril de 1287, declara haver rebut en comanda de Benevuto de Capillario, pisà, 80 gerres de cansalada per al viatge que es diposa a emprendre en la nau "Pignola", cap a Gènova: Ibidem, doc. 251, p. 154.

${ }^{10.3}$ Especialment vers Pisa i Gènova, on disposaven de cònsol des del 1277 i el 1279 respectivament [ACA, C, reg. 39, fol. 212 r.; i reg. 44, fol. 138 v.].

${ }^{104}$ I. DORIA, Annales Ianuenses, p. 78.
} 
carregaments pisans ni es dirigeixen a la plaça toscana, justificant la intercepció per haver-los sorprès navegant en aigües jurisdiccionals o amb coserva amb navilis de l'esmentat Comú. Convé no oblidar que la nostra principal font d'informació no es neutral, que depenem d'Iacopo Doria, un dels analistes lígurs, el qual, com qualsevol altre cronista oficial, deu tendir a convertir en atacs corsaris autèntiques agressions piràtiques. Les escomeses, arbitàries o justificades, devien provocar respostes idèntiques i de signe contrari per part dels damnificats, alguns dels quals obtenen del sobirà una llicència de marca ${ }^{105}$. La potència naval de Gènova i la conjuntura política vigent, del 1282 ençà, a la Mediterrània no permetien al comte-rei anar més enllà.

El blocus establert pels lígurs en torn a les boques de l'Arno esdevé tan asfixiant que, el desembre de 1287, els partidaris de la pau amb Gènova s'alcen, a Pisa, contra el govern del comte Ugolino. El negoci hi havia decaigut fins a cotes insospitades, una part important de la joventut llanguia als càrcers lígurs, per tal com cap dels nombrosos presoners capturats tres anys abans a la Melòria havia estat encara lliurat, i les famílies nobiliàries sardes es mostraven receptives a les ofertes formulades pels representats de la principal potència naval del Tirrè. Després d'uns mesos de indecisió, a començament d'abril de 1288, el Consiglio Generale de Pisa acepta l'obertura de negociacions amb els antics enemics; uns quants dies després, el 15 exactament, es signa, a Gènova, la pau ${ }^{106}$. Els termes de l'acord són especialmet durs per als toscans, per tal com es comprometen a transferir al lígurs, en el termini d'un any, la ciutat, el burg, el port i les salines de Càller, la ciutat i els burgs de Sàsser, i el castell de Mons Draconus, al giudicato de Torres; s'engatjen a derruir, abans de divuit mesos, la torre, la muralla i els edificis aixecats, en solars pertanyents al barri dels genovesos, a Acre, a no reconstruir les fortificacions de l'illa de Pianosa i a depositar, com garantia de compliment de totes aquestes imposicions, 5.000 lliures en diverses ciutats; renuncien, a més, a tots els drets de què disposaven sobre

\footnotetext{
${ }^{105}$ Alfons el Lliberal, el 1286, va concedir un lou de 8 diners per lliura sobre totes les mercaderies lígurs que passessin per València, per tal d'indemnitzar un ciutadà de la capital llevantina a qui havien robat les mercaderies a Gènova: ACA, C, reg. 66, fol. 199 r.; regest. R. GALlofRÉ, Documentos del reinado de Alfonso III de Aragón relativos al antiguo reino de Valencia y contenidos en los registros de la Corona de Aragón, Valencia, Institución Alfonso el Magnánimo, 1968, doc. 356.

${ }^{106}$ Liber Iurium Reipublicae Genuensis, II, pp. 127-164. P. LISCIANDRELLI, Trattati e negoziazioni, p. 91, n. 434. G. CARO, Genova sul Mediterraneo, II, pp. 91-95.
} 
l'illa de Còrcega. Els lígurs retenien un presidi en el castell de l'illa d'Elba i condicionaven al cumpliment previ de totes aquestes obligacions i garenties l'alliberació dels cautius pisans. Un cop evacuat Càller, els toscans hi conservarien el dret d'adquirir anualment 3.000 mines de sal, al preu de 2 diners la mina, i només podrien recalar al port dues naus i tres vaixells petits al mes, per a vendre mercancies i comprar queviures. Aquestes rígides barreres comercials tenien per finalitat desvincular econòmicament i política Sardenya de Pisa. Per tal d'intensificar-ne el control, les autoritats lígurs concedeixen als seus súbdits llibertat de comerç $\mathrm{i}$ immunitat aranzelària $\mathrm{a}$ l'illa. Les condicions eren tan oneroses que difícilment podien ser complides pels pisans, ja que significarien la liquidació del seu comerç exterior; les acceptaren per guanyar temps, sense voluntat de servar-les. Les reserves mentals dels vençuts no van passar desapercebudes pel sector amb més experiència política de la societat genovesa: l'annalista Iacopo Doria ${ }^{107}$ només esmenta breument la conclusió de la pau, sense recollir els grans avantatges obtinguts per la República.

La concurrència creixent entre els catalans i el genovesos a la Mediterrània occidental i central i la notícia que Carles II de Nàpols ha obert contactes diplomàtics amb la República lígur per tal d'assegurar-se'n el suport naval inciten als consellers de Jaume d'Aragó, durant el primer semestre de 1290, a accentuar el control sobre l'activitat comercial dels lígurs als mercats sicilians ${ }^{108}$, tot respectant escrupulosament el favorable estatut aranzelari de què hi gaudien, i a oferir a Oberto Spinola i Corrado Doria un tractat de pau i de col·laboració ${ }^{109}$. El Comú, per aquesta època, estava concentrat, tanmateix, en la culminació d'una gran ofensiva contra Pisa, destinada a destruir la seva infrastructura defensiva, molt malmesa arran del desastre de la Melòria. Una esquadra lígur, durant l'estiu de 1290, ataca Porto Pisano i Livorno i s'apodera de l'estratègica illa d'Elba ${ }^{110}$; el context no era, doncs, el més adient perquè tot dos Capitani examinessin

\footnotetext{
${ }^{107}$ Annales Ianuenses, pp. 82-89.

${ }^{108}$ Berenguer de Vilaragut, cap el mes de febrer de 1290 , notifica a Jaume d'Aragó qu.en Palerm naus de Jeoveses són vengudes $e$ an aportades letres qui són trameses de mercaders a mercaders e qui són estades fetes en Jènova e en altre parts: ACA, CRD, Templaris, 204; ed. H. Finke, Acta Aragonensia, Berlin-Leipzig, W. Rotschild, III, 1922, doc. 4, p. 6.

${ }^{109} \mathrm{G}$. CARo, Genova sul Mediterraneo, II, p. 158.

${ }^{110}$ I. DORIA, Annales Ianuenses, pp. 117-118. G. STElla, Annales Genuneses, col. 984. G CARo, Genova sul Mediterraneo, II, pp. 135-152.
} 
detingudament les ofertes formulades pels agents del comte-rei. El març de l'any següent, era Carles II qui, amb la col-laboració de dos cardenals, intentava -infructuosament - involucrar la República en la reconquesta de Sicília ${ }^{11 !}$.

Malgrat el fracàs de la Santa Seu i de la cort napolitana en l'intent d'atreure's la Diarquia gibel-lina, les relacions entre el Comú i la Corona d'Aragó, a la primavera de 1291, no eren fluides. L'increment de la col-laboració mercantil amb Pisa, el menyspreu del blocatge establert per Gènova al Tirrè i l'alça dels contingents de cereals sicilians captats i exportats directament pels súbdits del comte-rei acaben per provocar una escalada d'incidents entre embarcacions lígurs i catalanes a la Mediterrània central. El canvi de to en les relacions el marca, a l'entrada de l'estiu, la recuperació, prop de Forte Troia ${ }^{112}$, per una esquadra genovesa - integrada per la nau armada d'Ansaldo de Savignone i dues galeres capitanejades per Nicolino de Petracio- d'una nau interceptada per una flotilla pisana a l'illa d'Elba. L'embarcació, en el moment de la represa, navegava amb el pavelló quadribarrat amb destinació a Sicília, ja que els captors, a fi de dificultar-ne el recobrament, l'havien permutada, en el decurs d'una escala a Piombino, per una nau catalana de dues cobertes força més petita ${ }^{113}$. L'esmentat estol lígur, poques setmanes deprés, s'apodera, en aigües de l'illa del Giglio, d'una nau siciliana de gran tonatge, l'Aquila, carregada de blat, propietat de Jaume d'Aragó, valorada en la considerable quantitat de 7.350 lliures genoveses ${ }^{14}$, i d'una altra nau catalana que, provinent de Càller, es dirigia a Porto Pisano, valorada en 4.600 lliures genoveses ${ }^{115}$.

Els catalans i el sicilians, per la seva part, armen embarcacions i, des dels estratègics ports de Trinàcria, intercepten les flotes lígurs que, des de Llevant o Tunis, tornaven a Gènova. L'ofensiva s'obre, el mes de juny, amb l'enfrontament, dintre del port de Tunis d'una galera i d'una sagetia lígurs,

\footnotetext{
"II. DoriA, Annales Ianuenses, p. 123. G. CARO, Genova sul Mediterraneo, II, p. 158.

${ }^{112} \mathrm{Al}$ sud de Piombino, davant Porto Longone: C. Imperiale di Sant'Angelo, nota 1 a p. 126 dels Annales Ianuenses d'I. DORIA.

${ }^{113}$ I. DORIA, Annales Ianuenses, pp. 125-126.

${ }^{114}$ I. DORIA, Annales Ianuenses, p. 127. El monarca no va trigar a recuperar el vaixell, ja que el confiava, el juliol de 1292, al Mestre Portolà de Sicília, perquè l'administrés [ACA, C, reg. 95, fol. 86 r.; ed. A. DE STEFANO-F. GIUNTA, Codice diplomatico dei re aragonesi di Sicilia, II, Palermo, 1956, doc. 191, p. 102].

${ }^{115}$ I. DORIA, Annales Ianuenses, pp. 126-127.
} 
conduïdes per Raffo de Gualterio, amb una galera siciliana. La forta reacció de l'embarcació illenca no sols posa en fuita la sagetia, sinó que captura a més la galera lígur i la trasllada a Palerm. Entre les víctimes del combat figura el capità atacant ${ }^{116}$.

Els canvis polítics que es produeixen paral-lelament a Gènova i a la Corona Catalano-aragonesa durant el segon semestre de 1291 tendeixen a complicar encara més les relacions bilaterals, molt tenses però no trencades oficialment. El 18 de juliol, quan es disposava a traslladar-se a Roma per normalizar les relacions amb la Santa Seu, mor, en plena joventut i sense descendència, Alfons el Liberal. Uns quants mesos abans, el comte-rei, davant els problemes interns que generava la llarga guerra del Vespro, especialment entre la noblesa aragonesa ${ }^{117}$, i les favorables perspectives que obria a l'escenari ibèric la controvertida successió d'Alfons $\mathrm{X}$ de Castella ${ }^{118}$, havia subscrit el tractat de Tarascó. En virtut d'aquest acord, Carles de Valois, a canvi dels comtats d'Anjou i de Maine i dels districtes orientals del de Tolosa, renunciava a la Corona Catalano-aragonesa, Alfons el Liberal es desprenia formalment de Sicília i sotmetia a l'arbitratge pontifici el destí definitiu de les Illes Balears, i la Santa Seu es comprometia a normalitzar la situació canònica del comte-rei i a autoritzar el seu matrimoni amb Elionor d'Anglaterra ${ }^{119}$.

\footnotetext{
${ }^{116}$ I. DORIA, Annales Ianuenses, p. 132. G. CARO, Genova sul Mediterraneo, II, p. 159.

${ }^{117} \mathrm{~A}$ la qual havia hagut de concedir, el 28 de desembre de 1287, el Privilegio de la Unión, que representava una important minva del poder reial al territori interior, per tal com obligava el monarca a convocar-hi Corts anualment, el dia de Tots Sants, i el privava de les facultats de detenir o d'embargar béns a cap noble sense una sentència prèvia del Justícia: L. GoNZÁLEZ ANTÓn, Las uniones aragonesas y las Cortes del reino (1283-1301), Saragossa, CSIC, 1975, I, pp. 201-214.

${ }^{118}$ Que anava provocant, des del 1284, l'enfrontament del secundogènit, Sanç IV, amb els descendents del difunt hereu, els infants de la Cerda. Alfonso de la Cerda, refugiat a Aragó, amb el concurs d'alguns nobles castellans exiliats, entre els quals sobresortia Diego López de Haro, s'ha proclamat rei de Castella, a Jaca, el 1288, i ha ofert a Alfons el Liberal, a canvi de la seva col-laboració militar en la reconquesta de Castella, el districte fronterer de Múrcia: $\mathbf{R}$. MunTANER, Crònica, "Les Quatre Grans Cròniques", pp. 812-813; J. ZuriTA, Annales de la Corona de Aragón, II, pp. 375-378.

${ }^{119}$ R. MUNTANER, Crònica, pp. 823. V. SALAVERT, Cerdeña y la expansión mediterránea de la Corona de Aragón, 1297-1314, Madrid, CSIC, 1956, I, pp. 78-80. S. RunCIMAN, I Vespri siciliani, pp. 348-349.
} 
3. La participació creixent dels catalans en el comerç exterior sícul accentua la hostilitat dels lígurs

La prematura desaparició de l'Alfons el Liberal col-locava, doncs, el secundogènit de Pere el Gran al capdavant de la Corona Catalanoaragonesa, tot esdevenint-ne Jaume II. El nou monarca, que no renuncia a la sobirania de Sicilía, davant les Corts de la qual acredita com a lloctinent el seu germà Frederic ${ }^{120}$, es declara desvinculat de qualsevol acord signat pel seu antecessor. El retorn a la situació vigent durant la segona fase del regnat de Pere el Gran, amb el restabliment de la unió d'ambdues corones en la persona del comte-rei, reforçarà la presència política i econòmica de la "Confederació" Catalano-aragonesa a la Mediterrània, afavorirà la penetració comercial dels barcelonins, mallorquins i valencians a Trinàcria i conferirà un nou impuls al front gibel-lí a Itàlia. Nicolau IV contesta la denúncia dels acords de Tarascó tot excomunicant de nou els "rebels" i el seu coordinador. Els francesos i els napolitans, arran del blocatge de la via diplomàtica, reprenen els preparatius bèl-lics. Jaume II, conscient de la imminent ruptura d'hostilitats, referma els vincles amb alguna de les famílies més representatives del gibel-linisme lígur ${ }^{121}$ i normalitza les relacions amb Sanç IV de Castella a Monteagudo ${ }^{122}$.

L'esgotament paral-lel del sistema de la doble capitania, amb la susbstitució, el 28 d'octubre de 1291, d'Oberto Spinola i Corrado Doria per Lanfranco de Suardi, ciutadà de Bèrgam, atenua la influencia dels gibel·lins a Gènova i esdevé un factor d'inestabilitat política ${ }^{123}$. Els canvis -simultànis

${ }^{120}$ I. DORIA, Annales Ianuneses, p. 131. R. MUNTANer, Crònica, pp. 824-825. J. ZURITA, Anales de la Corona de Aragón, II, pp. 416-421. H. FinKE, Acta Aragonensia, I, 1908, p. 8. S. Runciman, I Vespri siciliani, p. 350.

${ }^{121}$ Autoritza, l'1 d'octubre de 1291, Gabriele Spinola a extreure de Sicília 500 salmes de forment [ACA, C, reg. 90, fol. 62 r.; ed. A. DE STEFANO-F. GIUNTA, Codice diplomatico dei re aragonesi di Sicilia, II: anni 1291-1292, Palermo, 1956, doc. 32, p. 48]; tres dies després, ordena a l'infant Frederic que lliuri a Cristiano Spinola les 120 I. que li havia promés [ACA, C, reg. 90 , fol. 65 r.; ed. Ibidem, doc. 35 , p. 50]

${ }^{122} \mathrm{La}$ concòrdia entre ambdós regnes va ser reforçada amb el casament del jove sobirà català amb Isabel, la primogènita del rei de Castella. Sanç IV s'havia compromès, a més, a servir de mitjancer entre Jaume II i els coordinadors del front franco-angeví i la Santa Seu: R. Muntaner, Crònica, pp.826-827; J. ZuRITA, Anales de la Corona de Aragón, II, pp. 422-429 H. Finke, Acta Aragonensia, I, pp. 11-13; V. SAlaverT, Cerdeña, I , pp. 85-89; M. GaibroIs, Historia del reinado de Sancho IV de Castilla, II, Madrid, 1922, pp. 139-149. $153-156$.

${ }^{123}$ I. DORIA, Annales Ianuenses, pp. 123-124. G. CARO, Genova sul Mediterraneo, II, pp. 
i de tendència contrària - operats al front dels "Executius" de la Corona Catalano-aragonesa i del Comú lígur modifiquen la relació de forces vigent a la Mediterrània i hi accentuen les tensions i els enfrontaments.

Poques setmanes després que Jaume II abandonés Sicília amb destinació a Barcelona, durant l'estiu de 1291, Nicolino de Petracio, amb les seves dues galeres, captura, a les immediacions de Porto Pisano, dues naus catalanes carregades de blat $i$ les desvia cap a Gènova ${ }^{124}$

El triomf obtingut, al port de Tunis, el proppassat mes de juny ${ }^{125}$ anima els sicilians i els catalans a continuar la seva ofensiva contra les embarcacions lígurs. Durant l'agost, tres mesos després de la caiguda d'Acre en poder dels mamemulcs, una galera i un galió armats a Messina sorprenen, prop de l'illa de Tano, la galera de Manuele Lercari, que tornava d'Alexandria. L'embarcació lígur, descartada la fuita, es llança contra la galera atacant, tot obrint-li una via d'aigua que l'obliga a batre's en retirada ${ }^{126}$. El fet que el vaixell genovès hagués violat la recent disposició pontifícia que prohibia als cristians comerciar amb Egipte ${ }^{127}$ conferia una certa coartada moral als agressors i explica que, de retorn a Gènova, el capità fos sancionat amb una multa de 1000 lliures $^{128}$. Poc dies després del frustrat abordatge, el galió sicilià és capturat per homes de $\mathrm{Morea}^{129}$. La galera, reparats els desperfectes, decideix, malgrat el pèssim inici de la campanya, romandre al Jònic a l'espera d'alguna embarcació lígur. Dues galeres mercants genoveses, les de Sorleone Doria i Gazzella Avvocato, coincideixen, en aigües de Corfú, amb l'esmentat vaixell sícul. Els patrons continentals, considerant que la relació de forces els era favorable, intenten abordar la galera illenca. L'eficàcia defensiva dels ballesters catalans, tanmateix, no tan sols frustra

\footnotetext{
${ }^{124}$ I. DORIA, Annales Ianuenses, p. 131.

${ }^{125}$ Vegeu supra, nota 116

${ }^{126}$ I. DORIA, Annales Ianuenses, p. 132-133. G. CARO, Genova sul Mediterraneo, II, p. 159.

${ }^{127}$ Vegeu supra, pp. 735-736.

${ }^{128}$ I. DORIA, Annales Ianuenses, p. 133.

${ }^{129}$ Ibidem.
} 
l'operació sinó que causa, a més, nombroses baixes entre els atacants ${ }^{130}$. Gazzella Avvocato encapçala la llista dels caiguts.

L'incident, que segons l'analista Jiacopo Doria va excitar la sobèrbia dels catalans ${ }^{131}$, palesa que les embarcacions lígurs navegaven amb armament insuficient. Les autoritats genoveses, per tal d'evitar futures pèrdues, prohibeixen que cap galera ultrapassi Porto Pisano si no porta a bord almenys 20 ballesters i un carregament de 180 bales o de 750 quintars $^{132}$. L'emergent poder naval català obliga, per primera vegada, Gènova, un empori de llarga tradició marinera $\mathrm{i}$ al tuc de la prosperitat comercial, a adoptar mesures defensives davant una nova concurrent que, tant per la seva audàcia i noves tècniques de combats com per les bases d'avituallament al seu abast, es revela cada cop més perillosa. La balança, tanmateix, s'inclina, com ho palesa el nombre d'embarcacions capturades para cada una de les parts, del cantó lígur.

L'escalada de l'agressivitat catalano-sícula a la Mediterrània central i la recent reestructuració político-administrativa empenyien la República lígur cap al bàndol antiaragonès. L'aliança franco-angevina, per altra part, no disposava d'uns efectius i d'una experiència navals suficients per a recuperar Sicília; la principal potència marítima de la conca occidental de la Mediterrània continuava essent Gènova. Carles II, amb la cooperació del papa Nicolau IV $^{133}$, intentava aconseguir el trencament de la neutralitat lígur a la guerra del Vespro, el noliejament d'embarcacions lígurs, que tan eficaces s'havien mostrat contra els pisans, per a expugnar els catalans de Trinàcria. A fi de conjurar aquesta perillosa aliança, Frederic de Sicília havia inciat la seva lloctinença confirmant, el 20 de juliol de 1291, tots els

\footnotetext{
${ }^{130}$ "Catalani vero ipsos tantum oppresserunt balistis, quod galioti ceperunt fugere ab alia parte galee, ac totam bandam ipsam posuerunt in mari, ut possent melius a balistis evadere. Multi etiam ex galioti se precipitaverunt in mare, et si Catalani bene recordati fuissent, eam cepissent de levi. Alia vero galea dicti Surleonis, volvens se retro, cepit eandem persequi, quam etiam multum cum balistis oppressit. Cum autem in galeis Ianuensium essent multi vulnerati et etiam dictus Gazella et plures alii mercatores mortui, desisterunt eam persequi": I. DORIA, Annales Ianuenses, pp. 133-134.

131 "Unde ipsi catalani, per ea que eis acciderunt in superbiam elati et venientes Messanam, ceperunt ufanias multas dicere, et velle unam de suis galeis pugnare de cetero contra duas galeas hominum Ianue": I. DORIA, Annales Ianuenses, p. 134.

${ }^{132}$ Ibidem, p. 134.

${ }^{133}$ Que va enviar a Gènova l'arquebisbe de Reggio, per tal de pressionar les autoritats locals a favor de la cort de Nàpols i prohibir-hi tota mena de comerç amb Trinàcria: G. CARO, Genova sul Mediterraneo, II, p. 159
} 
privilegis concedits pel seu germà, Jaume d'Aragó, als lígurs ${ }^{134}$. Les concessions no van impedir, emperò, que molts de ciutadans genovesos, alarmats per la creixent hostilitat de les marineries local i catalana, abandonessin les places illenques ${ }^{135}$. L'abril de 1292, és Jaume II d'Aragó qui pren la iniciativa i encarrega a Oberto della Volta la presentació, al Comú i a un conjunt de personalitats de gran rellevància política ${ }^{136}$, d'una oferta de renovació i ampliació dels acords vigents entre ambdós estats ${ }^{137}$. La proposta estava redactada en uns termes pràcticament idèntics als de la de Frederic: si Gènova manté la seva neutralitat al contenciós catalanoangeví, podrà continuar aprovisionant-se de cereals i d'altres productes als territoris insulars i continentals de la Corona Catalano-aragonesa, on els seus ciutadans continuaran gaudint de llibertat de comerç i de reduccions aranzelàries; els súbdits del comte-rei que, en els passats enfrontaments navals, haguessin comès arbitrarietats contra els genovesos seran castigats. El sobirà demana als ciutadans lígurs, molts dels quals, poc després de la seva partença de Palerm, es van replegar dels mercats sicilians, que tornin a operar a l'illa, per tal com les seves persones i béns hi estan protegits per garanties fermes ${ }^{138}$.

Dels resultats de l'ambaixada, no en tenim informació; els incidents entre embarcacions d'ambdues banderes, tanmateix, van continuar durant l'any 1292, encara que a un ritme quelcom inferior. El 22 de maig s'enfronten, prop de Columbaia ${ }^{139}$, una galera barcelonina amb destinació a Trapani, en que viatjava un ambaixador de Jaume II, i la galera genovesa de Franceschino Caravello; els genovesos, després de delmar la tripulació i comprovar la seva nacionalitat, van permetre a l'embarcació catalana conti-

\footnotetext{
${ }^{134} \mathrm{G}$. CARO, Genova sul Mediterraneo, II, p. 160.

${ }^{135}$ Vegeu infra, nota 138.

${ }^{136}$ Entre les quals figuraven els dos precedents capitans, Oberto Spinola i Oberto Doria, el feel partidari del comte-rei Filippo della Volta i els dirigents de la facció gibel.lina més predisposats a una entesa amb la casa de Barcelona: Vegeu infra, nota 137.

${ }^{137}$ ACA, C, reg. 252, fols. 31 r.-32 v.; ed. C. Batlle a A. DE Capmany, Memòrias Históricas de Barcelona, II-1, doc. 48, pp. 72-74. J. ZURITA, Anales de la Corona de Aragón, II, p. 434

1.38" Maraveilas los senyor rey que 1 ha oyt dir que, depús la sua partensa del regne de Sicília, que $\cdot$ Is jenoveses se són estrenaytas del regne de Sicília; e par al senyor rey que açò no deien fer, qu-axí segurament bé poden anar e estar en aquell regne, com fer solien; e axí los prega lo senyor rey que els lo facen, e axí conexerà ell que ells li porten aquella amor que ell se cuyda": Ibidem.

${ }^{139}$ Una de les illes Egates.
} 
nuar viatge $\mathrm{e}^{140}$. Aquest triomf puntual produeix una gran alegria a l'analista lígur, pel fet de palesar que els "superbs" catalans continuaven essent vulnerables ${ }^{141}$.

El paper decisiu que jugaven Sícilia i les Illes Balears en la seva xarxa de vies comercials i l'eficiència de l'almirall Roger de Llúria induïen els nous dirigents del Comú a no cedir a la pressió d'un sector de la seva marineria, alarmat per l'ascens de la concurrència catalana. Durant l'estiu de 1292, una flota de vuit galeres genoveses intercepta, entre Monte Argentario i Piombino, una nau siciliana carregada de blat que Roger de Llúria enviava a Pisa, on hi havia una carestia, i la desvia cap a Gènova. L'abordatge provoca entre la tripulació agredida vint-i-tres morts i nombrosos ferits greus. Les autoritats de la República, per tal de conjurar la imminent represàlia de l'almirall sicilià, s'apressen, emperò, a reintegrar l'embarcació i el carregament als propietaris i demanen formalment disculpes a Frederic d'Aragó ${ }^{142}$. Jaume II, uns quants mesos després, a mitjan setembre, actua de forma parescuda: després d'autoritzar Salvo Cao i Pascasio de Santo Donato a extreure de Sicília, lliure d'impostos, blat per valor de 72 lliures 14 sous barcelonesos, quantitat en què havien estat valorats els danys que els van inferir uns catalans quan van atacar la seva nau ${ }^{143}$, concedeix a Filippo de Marini una llicència de treta de 2.208 salmes de forment, exemptes d'aranzel, en concepte de retorn d'un préstec que va concedir, el 1291, a Alfons el Liberal ${ }^{144}$. Aquest comportament mesurat i prudent dels dos governs devia suscitar, tanmateix, poc entusiasme, si no desil-lusió, a un sector dels respectius súbdits, en què s'havia anat arrelant -com es desprèn de la lectura dels annals de Jiacopo Doria ${ }^{145}$ - una creixent hostilitat recíproca.

Des del 1284, amb motiu del blocatge naval establert per Gènova contra Pisa, ha esclatat una guerra de cors entre els lígurs, d'una part, i els

\footnotetext{
${ }^{140}$ I. DORIA, Annales Ianuenses, p. 139.

141 "Quod quidem hominibus Ianue valde fuit acceptum, quoniam Catalani in tantam erant elati superbiam, quod cottidie, in Sicilia et ubique, improperabant homines Ianue se cum una ex suis galeis velle duas galeas Ianuensium expugnare": I. DORIA, Annales Ianuenses, p. 139. 162.

${ }^{142}$ I. DORIA, Annales Ianuenses, pp. 145-146. G. CARO, Genova sul Mediterraneo, II, p.

${ }^{143} \mathrm{ACA}, \mathrm{C}$, reg. 95, fol. 118 r.; ed. A. De Stefano-F. GiunTa, Codice diplomatico di Sicilia, II, doc. 252, p. 252.

${ }^{144} \mathrm{ACA}, \mathrm{C}$, reg. 95, fol. 121 r.; ed. Ibidem, doc. 254, p. 253.

${ }^{145}$ Vegeu supra, nota 131.
} 
catalans i els sicilians, de l'altra. Les autoritats de la ciutat-estat i de la "Confederació" segueixen de prop els esdeveniments, conscients que cada atac, pel fet d'introduir inseguretat, distorsionar el funcionament del comerç exterior i ocasionar pèrdues materials i humanes, debilita l'altre i reforça les posicions pròpies. Els incidents, protagonitzats per particulars, degraden però no trenquen les relacions diplomàtiques bilaterals, els contactes a nivell d'estats. Mentre el saldo de danys es mantingui gairebé equiparable i els menyscaptes econòmics $i$ humans es considerin inferiors als costos d'armament $\mathrm{i}$ de manteniment d'una flota, a les despeses d'una guerra naval convencional, les autoritats de Gènova i de Barcelona animaran tàcitament les respectives marineries a continuar els atacs i s'intercanviaran públicament disculpes, no pas reparacions efectives, pels danys recíprocs.

Gènova manté un contenciós amb Pisa per la supremacia a la mar Tirrena i pel control de la plaça i de les salines de Càller. El principal antagonista de la Corona Catalano-aragonesa és el front franco-angeví, interessat a recuperar Sicília. La necessitat de mantenir ambdós contenciosos separats obliga, doncs, les autoritats de la República i de la "Confederació" a dosificar amb precisió l'agressivitat dels seus respectius súbdits, per tal que no comprometin les fredes relacions existents ni transmutin un concurrent orc en un enemic notori. Amb aquest enfrontament de baix nivell, Gènova i la Corona Catalano-aragonesa no dirimeixen tan sols el control mercantil de Sardenya i Trinàcria, sinó el domini, a termini mitjà, del Mediterrani central. La ubicació dels incidents dibuixa dues àrees calentes. Els genovesos efectuen la major part dels seus atacs al Tirrè, especialment a la seva meitat septentrional, en el quadrilàter comprès entre Bonifacio, Civitavecchia, Portovenere i Monaco. En aquesta zona, esquadres lígurs efectuen, entre 1284 i 1292, vuit atacs, cap de fallit, i hi capturen cinc embarcacions catalanes i quatre de sicilianes. Aquest alt rendiment és imputable tant a la proximitat de les bases de sortida de les flotes atacants com a l'eficaç funcionament del sistema de blocatge establert per Gènova, després del triomf de la Melòria, entorn a les boques de l'Arno, per tal de dificultar l'abastament cerealístic de Pisa des de Càller i Palerm. Fora de l'esmentat quadrilàter, vaixells del Comú efectuen coetàniament quatre abordatges, tres dels quals, els de Càller, Fréjus i Columbaia, es tanquen amb la captura del vaixell; a l'altre, el de Corfú, la manifesta superioritat naval dels atacants és neutralitzada efiçacment pels ballesters catalans.

Els súbdits ibèrics i ultramarins de Jaume II d'Aragó tendeixen, en canvi, a concentrar les escomeses a la mar Jònica i al Canal de Sicilia, per 
on han de passar necessàriament les principals flotes italianes tant a l'anada com a la tornada de Llevant i del Magrib Oriental. El 1291, esquadres catalanes i sícules hi efectuen dos atacs i capturen una galera lígur. El fracàs d'un dels abordatges, prop de Morea, queda compensat pel refús amb éxit, en aigües de Corfú, d'un intent d'intercepció.

Aquesta guerra de cors llasta però no impedeix l'enfortiment dels vincles comercials entre Catalunya, València i les Illes Balears i Sicília, entrebanca però no neutralitza l'alça de l'activitat dels ciutadans de la "Confederació" a Trinàcria. Segons les llicències de treta venudes per la Tresoreria reial i les concedides gratuitament pel sobirà, de què ha quedat testimoni als registres de la Cancelleria, els súbdits ibèrics del comte-rei, només el 1292, van adquirir a Sicília 47.281 salmes 1 1/3 tomins de blat, 34.567 de les quals (el 73,1 \%) van ser exportades per mercaders barcelonins ${ }^{146}$. Un sol mercader de la ciutat comtal, Berenguer de Finestres, pel març de 1292, va obtenir de Jaume II, en pagament de 150.000 sous barcelonesos, resta d'un préstec que va concedir al difunt Alfons el Liberal, una llicència d'exportació de 25.000 salmes de blat (unes $5.625 \mathrm{tm})^{147}$. A aquestes quantitats s'han de sumar encara les partides el dret de treta de les quals no va ser pagat pel concessionari a la Tresoreria sinó directament, com era costum, al Mestre Portulà de Sicília, de què no disposem de constància documental. Encara que una part d'aquest important contingent de blat s'encaminés cap a la Itàlia septentrional ${ }^{148}$ o Berberia -les llicències no especifiquen les destinacions dels carregaments- el gros es degué adreçar, sens dubte, a les grans ciutats catalanes, balears i valencianes. Les exportacions de cereals devien constituir un negoci molt rendible, per tal com ben prest es va organitzar, entre els mercaders catalans i instal-lats a l'illa, un mercat de llicències de treta ${ }^{149}$.

\footnotetext{
${ }^{146}$ A. De Stefano-F. Giunta, Codice diplomatico dei re di Sicilia. II, passim.

${ }^{147}$ ACA, reg. 193, fol. 186, i reg. 93, fol. 209 r.; ed. A. DE STEFANO-F. Giunta Codice diplomatico di Sicilia, II, doc.84, pp. 106-108, i doc. 210, p. 220.

${ }^{148}$ Tot seguint la senda d'Arnau Panides, barceloní, que l'1 de febrer de 1287 havia declarat haver rebut, a Palerm, en comanda de Bernat de Sant Emeteri i Bernardó Tripó, catalans, 40 salmes de blat, per al viatge que es diposava a emprendre, en la nau de Joan Vives, mallorquí, cap a Gènova [P. Bugarella, Le imbreviature del notaio Adamo de Citella, I, doc. 105, pp. 76-77]. Pisa era un altre dels mercats de destinació probable per als carregaments de cereals sículs posats en circulació pels barcelonins vers 1290 [Vegeu supra, notes 113, 114 i 124].

${ }^{149}$ Jaume de Cànaves, barceloní, el 1287 ja havia declarat, a Palerm, haver venut a Simone d'Oddorisio, veí de Termini, la llicència que havia obtingut per a treure de l'illa 1300 salmes de blat: P. Bugarella, Le imbreviature del notaio Adamo de Citella, doc. 300, p. 183.
} 
Sicília es va convertint en un mercat on els genovesos, tot conservant l'estatut de nació més afavorida, topen, del 1291 ençà, amb uns concurrents nous però agressius, els catalans. Trinàcria, terra segura i de bons negocis, esdevé gradualment per als lígurs la platafamora d'un sistema de paranys estratègicament situat en el punt de confluència de les seves rutes de Llevant i d'Ifriqiya, el centre d'una àrea perillosa, com el Tirrè septentrional, per als catalans.

4. Nàpols ofereix als lígurs, a canvi d'un recolzament naval decidit contra els catalans, concessions comercials al "Mezzogiorno" $i$ a Provença

En aquestes circumstàncies, és lògic que -malgrat les precaucions de les corts de Barcelona i Palerm per preservar la neutralitat de Gènova en la llarga guerra del Vespro- els nous governants lígurs ${ }^{150}$, d'un gibel-linisme quelcom més feble que el dels cessats Oberto Spinola i Corrado Doria, es mostressin disposats a escoltar les ofertes del front franco-angeví. Les negociacions es van obrir el desembre de 1292. Els delegats de Carles II van oferir a Gènova una aliança ofensiva i defensiva perpètua o temporal, que implicaria el recíproc suport per a la reconquesta dels terrenys perduts. Els napolitans sol-licitaven, per a l'ofensiva que acabaven de desencadenar contra Sicília, una flota de 80 galeres lígurs; les despeses d'armament i de manteniment correrien a càrrec dels angevins, els quals es comprometien, a més, a aportar contingents militars en cas que Génova decidís expugnar els pisans de Càller. Els súbdits de la República gaudirien de llibertat de comerç a Nàpols, Sicília i Provença, on no haurien de pagar cap més aranzel que la taxa de recognició ${ }^{151}$ ni se'ls podria aplicar el dret de naufragi. La República lígur podria adquirir anualment al Mezzogiorno italià, un cop recuperada Trinàcria, 30.000 salmes de gra, per al mercat interior, exemptes de tota càrrega fiscal. L'angeví oferïa al Comú un préstec -retornable a llarg termini- de 200.000 lliures torneses, la meitat de les quals es farien efectives tot just signat l'acord, i rescabalar, a més, els ciutadans de la República de

\footnotetext{
${ }^{150}$ Els Capitani Lanfranco de Suardi, fins al setembre de 1292, i Beltrame de Ficino, immediatament després. Ambdòs governants eren de ciutadania bergamasca: I. CARO, Genova sul Mediterraneo, II, p. 155, nota 13.

151 "Nichil solvere teneantur nisi unum schifatum pro quolibet mercatore dandum doaneriis illius loci ubi exhoneraverint merces et res predictas vel partem earum": I. DoRIA, Annales Ianuenses, p. 155.
} 
les confiscacions que sofririen a Sicília, Mallorca i Catalunya ${ }^{152}$. Mentre Trinàcria restés en poder dels catalans, els lígurs tendrien garantides 200.000 mines de blat provençal i francès al preu invariable de 15 sous genovesos la $\operatorname{mina}^{153}$

La proposta angevina, ben articulada, intentava entrellaçar dos conflictes que fins aleshores havien evolucionat per separat, el de Sicília i el de Sardenya, garantir l'abastament frumentari del Comú a Provença i al Llenguadoc marítim fins a l'expugnació dels catalans del Mezzogiorno italià, finançar íntegrament el replegament dels homes de negocis lígurs dels dominis del comte-rei i millorar l'estatut mercantil i aranzelari de què gaudien a Trinàcria. L'efectivitat de la flota de Roger de Llùria, l'important paper que continuaven acomplint, malgrat els recíprocs incidents navals, algunes places de la Corona Catalano-aragonesa en la projecció exterior de Gènova i la mort de Nicolau IV ${ }^{154}$, un valedor decidit de Carles II, minvaven, tanmateix, l'atractiu de l'oferta napolitana entre els medis mercantils i financers lígurs.

Les autoritats genoveses, en el decurs d'unes llargues negociacions, eleven les seves exigències econòmiques i comercials. Reclamen el trencament de les relacions comercials entre el Regne de Nàpols, Provença i els dominis de l'Església i la ciutat-estat de Pisa. Càller, quan es conquereixi, haurà de passar al domini del Comú no sols de fet sinó de dret, amb la corresponent sanció del Col·legi Cardenalici i del futur Pontífex. Carles II haurà de renunciar a totes les posesions de què disposa en el comtat de Ventimiglia; els mercaders lígurs no estaran sotmesos, en els seus dominis actuals i futurs, a cap més impost comercial que una taxa de recognició i els cònsols de genovesos hi disposaran sobre els seus conciutadans del mer $\mathrm{i}$ mixt imperi i de la jurisdicció civil i criminal. El rei de França haurà

\footnotetext{
152" Item quod, si occasione presentis societatis, bona civium Ianue qui nunc sunt in insula Sicilie, Maioricarum vel Catalonie, qui quidem non sint cives seu incole vel burgenses dictorum locorum, arrestentur per inimicos domini regis, dictus dominus rex bona predicta in valorem ipsorum ipsis restituere teneatur": I. DoRIA, Annales Ianuenses, pp. 155-156.

${ }^{153} \mathrm{La}$ millor anàlisi de l'oferta napolitana - les clàusules de la qual van ser curosament transcrites per I. DORIA, Annales Ianuenses, pp. 152-159- continua essent la de G. CARO, Genova sul Mediterraneo, II, pp. 163-165.

${ }^{154}$ El 4 d'abril de 1292: I. DoRIA, Annales Ianuenses, p. 137.
} 
d'abolir l'escala preceptiva a Aigüesmortes ${ }^{155}$ per als vaixells amb destinació al Llenguadoc i a Provença, concedir als ciutatans de la República una exempció completa d'impostos comercial en els territoris sotmesos a la seva jurisdicció i comprometre's a no prohibir-los, en cap mena de circumstància, les exportacions de gra ${ }^{156}$.

Els contactes, per tal com els representants del rei de Nàpols no consideren assumibles les exigències del Comú, es tanquen sense resultats tangibles ${ }^{157}$. L'hostilitat creixent dels genovesos contra els catalans, cada cop més palesa, no ha assolit encara unes cotes suficients per decantar la República cap el front franco-angeví. Els gibel-lins, alguns dels quals han rebut favors del comte-rei ${ }^{158}$, continuen essent, sota el sistema de la capitania estrangera, un corrent polític més fort $\mathrm{i}$ ben organitzat que els güelfs. Gènova es manté, doncs, feel al seu tradicional neutralisme en el conflicte sicilià, preservant les seves relacions amb ambdós contendents ${ }^{159}$. Pregones i duradores seran, tanmateix, les conseqüències internes d'aquesta no-alineació: segons el cronista oficial, la posició a adoptar pel Comú en la llarga guerra de Sicília esdevé, des de desembre de 1292, una causa d'enfrontament a nivell d'estament $i$, fins i tot, de família ${ }^{160}$, un factor de divisió de la ciutadania que trigarà a tancar-se.

Les relacions amb la Corona Catalano-aragonesa continuen en la mateixa tònica: de pau teòrica, erosionada per puntuals atacs recíprocs de pirateria i per la recaptació de les corresponents marques. Durant el primer semestre de 1293, els mercaders genovesos eren perseguits, als dominis del

\footnotetext{
${ }^{155}$ Instaurada per Felip III el 1278, per tal d'accelerar el desenvolupament comercial de la nova plaça portuària, a càrrec de Montpellier, un domini gal infeudat a Jaume II de Mallorca: A. RIERA Melis, La Corona de Aragón y el Reino de Mallorca en el primer cuarto del siglo $X I V$, pp. 87-89.

${ }^{156}$ I. DORIA [Annales Ianuenses, pp. 160-165] inclou a la seva obra el text de la contraoferta lígur; un document que ha estat analizat amb força detall per G. CARO [Genova sul Mediterraneo, II, pp. 165-166]. $166-169$

157I. DORIA, Annales Ianuenses", pp. 150-151. G. CARO, Genova sul Mediterraneo, II, pp.

${ }^{158}$ Vegeu supra, notes 143 i 144.

${ }^{159}$ No sense qualque problema: els agents de Felip IV, arran del fracàs de les negociacions, confisquen mercaderies a noranta-quatre ciutadans lígurs a Nîmes i Aigüesmortes: I. DORIA, Annales Ianuenses, p. 151; G. CARO, Genova sul Mediterraneo, II, p. 168.

160 " Per predicta orta est divisio et dissensio sic magna, quod vicinus cum vicino, nobilis cum nobili, popularis cum populari, frater cum fratre, et quod plus est filius cum patre, in plateis et vicis graviter et turpiter contendebant": I. DORIA, Annales Ianuenses, p. 151.
} 
comte-rei, per nombrosos concessionaris de marques ${ }^{161}$. Per aquesta mateixa època s'havia reprès, a Gènova, la recaptació d'un antic lou contra els mallorquins ${ }^{162}$. Les represàlies recíproques compliquen els contactes mercantils però no els interrompen. Domènec Llull, barceloní, el maig de 1293, es trasllada a Gènova, en la nau de Nicolau Ros, amb diverses comandes ${ }^{163}$. Un altre mercader de la capital catalana, Bartomeu Oliver, nolieja, l'estiu de l'any següent, la nau tarragonina Santa Maria del Miracle per a exportar a Gènova de 1500 a 1800 salmes de forment sicilià ${ }^{164}$. Coetàniament, Jaume II concedeix llicències de treta de forment sicilià a Francesco Ciarra ${ }^{165}$, Filippo de Marini i Jacopo Squarciafico ${ }^{166}$. Que el blat circulava aleshores entre Trinàcria i Ligúria amb regularitat es desprèn també de les reiterades intercepcions de navilis carregat de gra, al Tirrè, per enemics de la República. Una esquadra pisana, el desembre de 1293, sorprèn dues galeres de mercat genoveses a l'illa de Peremola, on s'havien refugiat a causa d'una tampesta, i en captura una, valorada en 8.000 lliures genoveses ${ }^{167}$. Un any després, a la tardor de 1294 , la tarida lígur de Cantellino Cantello, provinent de Sicília, es interceptada a Gaeta, on el Capitano, per atenuar la fretura de pa que patia la ciutat, s'incauta del carragament de gra que transportava, propietat d'un romà ${ }^{168}$.

El fracàs de les negociacions amb els lígurs, la palesa inferioritat de la flota angevina respecte a la catalana, l'atenuació del suport francès, obligat a concentrar els seus efectius contra Anglaterra per la qüestió d'Aquitània, i del concurs pontifici, com a conseqüència de la complicada successió del

\footnotetext{
${ }^{161}$ Jaume II, el 8 d'abril, concedeix a Giacopo Squarciafico i als seus fills un salconduit vàlid per a tots els territoris sotmesos a la seva jurisdicció i una exempció d'aranzels: ACA, C, reg. 98, fol. 26 r.; ed. F. Giunta, N. Giordano, M. Scarlata i L. Sciascia, Acta siculoaragonensia, I-1, docs. 32 i 33, pp. 28-29.

${ }^{162}$ La supressió del qual és sol.licitada per Jaume II a les autoritats lígurs el 25 de maig de 1294: ACA. C, reg. 252, fols 87 r.-88 r.; ed. C. BATLLE a A. DE CAPMANY, Memorias Históricas de Barcelona, 2 ed, II-1, doc. 54, pp. 80-81.

${ }^{163}$ J.M. Madurell-A. García, Comandas comerciales barcelonesas, doc. 59, p. 198.

${ }^{164}$ F. DE Bofarull y SANS, Antigua marina catalana, "Memorias de la Real Academia de Buenas Letras de Barcelona", VII (Barcelona, 1901), pp. 72-74.

${ }^{165}$ ACA, C, reg. 261 , fol. 11 v.; ed. F. Giunta, N. Giordano, M. Scarlata i L. SCIASCIA, Acta siculo-aragonensia, I-1, doc. 29, p. 27. p. 300 .

${ }^{166} \mathrm{ACA}$, C, reg. 261 , fols. 246 v. i 254 v.; ed. Ibidem, doc. 355 , pp. 295-296, i doc. 359 ,

${ }^{167}$ I. DORIA, Annales Ianuenses, pp. 170-171.

${ }^{168} \mathrm{G}$. CARo, Genova sul Mediterraneo, II, p. 232, nota 6.
} 
bel-ligerant Nicolau IV ${ }^{169}$, i la possibilitat d'infiltrar-se en la ja bigarrada àrea dels Balcans que obria, el 19 de juliol de 1290, la mort sense descendència directa del seu cunyat Ladislau IV d'Hongria inciten Carles II de Nàpols a buscar una pau amb la Corona Catalano-aragonesa.

5. Els costos de la guerra obliguen els catalans i els napolitans a buscar una solució negociada per al conflicte de Sicília

La incorporació de Sicília -com ja s'ha exposat ${ }^{170}$ - havia afavorit els mercaders catalans, pel fet de refermar la seva penetració en ambdues conques de la Mediterrània, els fadristerns de la noblesa i el patriciat urbà del Principat, que hi van rebre beneficis i càrrecs ben retribuïts, i les capes mitjanes i baixes de les ciutats marítimes de la "Confederació", per tal com hi va atenuar les oscil-lacions del preu del blat i va estimular alhora la producció d'alguns sectors manufacturers. Les despeses de la llarga guerra marítima, emperò, sobrepassaven àmpliament els ingressos ordinaris d'Hisenda i només podien ser atesos amb increments successius de la pressió fiscal i amb préstecs onerosos dels potentats al sobirà, solucions que sempre acabaven perjudicant els més febles, per tal com els col-lectius solvents disposaven de mecanismes per a evadir o traslladar una part considerable de la seva quota tributària. Les importacions creixents de blat sicilià repercutien negativament, a més, damunt els senyors i els pagesos d'arreu de la Corona, en la mesura que minvaven el valor de canvi dels respectius excedents cerealístics. El descontentament era força palès a les terres interiors de la "Confederació", a la vall de l'Ebre, on es considerava que els costos i inconvenients de la conquesta de Trinàcria superaven amb escreix les rendes i els avantatges subseqüents. La discutida successió d'Alfons X el Savi a Castella, continuava oferint, per altra part, a la Corona d'Aragó unes interessants possibilitats d'intervenció a l'escenari ibèric. L'oferta del districte fronterer de Múrcia a canvi d'una aliança militar, formulada per Alfons de la Cerda, el desembre de 1288 , a Alfons el Liberal ${ }^{171}$, restava en peu. Dos anys al capdavant del govern de la Corona Catalano-aragonesa

\footnotetext{
${ }^{169}$ Que es va prolongar, arran de la divisió interna del Col.legi Cardenalici, més de dos anys, del 4 d'abril de 1292 al 5 de juliol de 1294, quan va ser elegit Pietro Morone, Celestí V, el candidat de Carles d'Anjou: S. Runciman, I Vespri Siciliani, p. 351.

${ }^{170}$ Vegeu supra, pp. 745-747.

${ }^{171}$ Vegeu supra, nota 118.
} 
havien atenuat el gibel-linisme inicial del comte-rei i l'havien induï a reanalitzar, amb uns plantejaments més realistes, l'evolució del seu antecessor envers el llarg conflicte del Vespro. Els acords de Tarascó ${ }^{172}$, que, des de Palerm i com a rei de Trinàcria, li van semblar una autèntica traïció a l'obra de Pere el Gran i a les legítimes aspiracions polítiques del poble sicilià, podien contenir, contemplats des de la perspectiva -més elevada- de Barcelona i en qualitat de cap de la "Confederació", aspectes positius. L'evacuació negociada de Sícilia comença a obrir-se pas, si més no com a possibilitat a termini mitjà, entre els assessors de Jaume II. Les qüestions es traslladen ara al camp de les contrapartides, de les compensacions territorials a rebre i dels mecanismes a establir per tal de preservar els rendibles vincles econòmics establerts, des del 1286, entre els principals ports de Trinàcria i Barcelona, Mallorca i València.

L'increment de la concurrència comercial entre Gènova i Venècia a Llevant, cọm a conseqüència de la caiguda d'Acre en poder dels mamelucs, dels vets comercials pontificis i del replegament forçat dels grans emporis islàmics, provoca un eventual desinterès del Comú lígur per la guerra de Sícilia i una atenuació transitòria de la presència naval de les dues grans repúbliques marineres a les rutes de Ponent ${ }^{173}$.

Totes aquestes circumstàncies, heterogènies però convergents, contribueixen, al llarg del 1293, a minvar la tensió a la Mediterrània occidental, a encarrilar-hi els conflictes pendents per la via de la negociació. Els contactes diplomàtics s'inicien, el juliol, a Logronyo, on, convocats per Sanç IV, es reuneixen Jaume II i Carles II $^{174}$. El comte-rei, incapaç de mantenir una guerra oberta en dos fronts, aprofita la voluntat de pau de Nàpols per a marcar distàncies respecte a Castella. En un context força diferent, l'entrevista de la Rioja és, doncs, el revers de la de Monteagudo ${ }^{175}$ : el 1291 es van sacrificar els drets dels infants de la Cerda i l'equilibri de poder a la Península Ibèrica a la conservació de Sicília; dos anys després, la política exterior de la Corona Catalano-aragonesa s'ha despolaritzat i l'afany de capitalitzar les dificultats interiors de Castella aconsella iniciar un trasllat d'efectius des del front mediterrani cap a la frontera occidental. A Logronyo,

\footnotetext{
${ }^{172}$ Vegeu supra, nota 119.

${ }^{173}$ G. CARO, Genova sul Mediterraneo, II, pp. 170-184

${ }^{174}$ I. DoRIA, Annales Ianuenses, pp. 169-170. V. SALAVERT, Cerdeña, I, pp. 95-98

${ }^{175}$ Vegeu supra, nota 122.
} 
s'intenta, doncs, consignar d'una manera més equilibrada els recursos diponibles, conjuminar l'expansió ultramarina de la "Confederació" i els plantejament mercantils de la burgesia amb la projecció continental i els interessos de l'aristocràcia feudal, arranjar la urbanitzada franja costanera amb el rerepaís rural.

Els contactes bilaterals van continuar, el desembre, als confins del Rosselló i l'Empordà ${ }^{176}$, on els dos sobirans van signar un armistici, en virtut del qual Jaume II s'avenia a considerar la posibilitat d'evacuar Sicília, si se'l compensava adientment amb metàl lic i amb teritoris ${ }^{177}$. Sis mesos després, Carles II aconsegueix imposar al dividit conclave el seu candidat, Pietro de Morone, que és consagrat amb el nom de Celestí V. El nou Pontífex, un ermità amb aura de santedat, no tenia, al revés del seu antecessor, cap mena d'experiència política. La seva actuació pública és dissenyada a Nàpols: avança a Carles II considerables quantitats de diners, provinents de les rendes eclesiàstiques d'Itàlia, França i Anglaterra, per finançar una nova ofensiva contra Sicília, li dóna sistemàticament suport en les seves negociacions amb Jaume II i amb el seu germà, l'infant Frederic $^{178}$

El 13 de desembre de 1294, Celestí V, incapaç d'assumir la responsabilitat inherent al càrrec, abdica el Soli per retornar a la vida contemplativa ${ }^{179}$. Nou dies després, el conclave elegeix Benedetto Gaetani, membre d'una important família de Campània, amb una ferma preparació política, que adopta el nom de Bonifaci VIII. El nou Pontífex, malgrat que com a cardenal havia tingut alguns enfrontaments amb la cort de Nàpols, va

\footnotetext{
${ }^{176}$ Mentre I. DORIA situa la trobada a Figueres [Annales Ianuenses, p. 170] i J. DE ZURITA dubta entre La Jonquera i Panissars [Annales de la Corona de Aragón, II, p. 453], V. SALAVERT suposa que va tenir lloc a la rodalia de la Jonquera [Cerdeña, I, pp. 98-102]

${ }^{177}$ En el projecte de pau sorgit de l'entrevista figura la clàusula següent: "Item dictum est, quod, si per dictum dominum regem Karolum aliqua provisio terre erga Ecclesia vel aliunde posset procurari pro ipso rege Aragonum, deducetur de quantitate marcharum, secundum quantitatem et valore provisionis procurate, videlicet, pro mille libris in redditibus $\mathrm{XV}^{\mathrm{M}}$ librarum deducantur, dummodo regi Aragonum placeat terra" [ACA, Pergamins, Extra invent., n. 3860; ed. V. Salavert, El Tratado de Anagni, doc. II, p. 289; Cerdeña, II, doc. 14, p. 12]

${ }^{178} \mathrm{~S}$. RUNCIMAN, I Vespri siciliani, p. 351.

${ }^{179} \mathrm{La}$ renúncia voluntària i l'opció per un ascetisme rigorós, de tipus eremític, fan de l'efímer pontífex una figura insòlita $i$ expliquen l'interès que va despertar entre els partidaris de la pobresa voluntària, els sectors més radicals dels les ordres mendicants $i$ els joaquinistes i altres apocalíptics.
} 
concedir al tema de Sicília, pel fet que repercutia negativament damunt el prestigi de la Santa Seu, una atenció preferent.

La davallada de l'agressivitat naval lígur i l'obertura de negociacions amb el front franco-angeví repercuteixen positivament, des del desembre de 1292 , en el comerç exterior català. Les exportacions de cereals sículs amb destinació als ports mediterranis ibèrics es multipliquen ${ }^{180}$. Entre el 25 de març de 1293 i la mateixa data de 1294, segons les llicències concedides pel sobirà, van ser tretes de Trinàcria, per ciutadans de la "Confederació", 74.997 salmes 12 tomins de forment; només els homes de negocis de la capital catalana en van adquirir 22.229 (el 29,6\%) ${ }^{181}$. Un dels principals exportadors es el mateix comte-rei: el 21 juny de 1293, ordena al Mestre Portulà que enviï 8.097 salmes i 8 tumoli de blat i 183 salmes i 4 tumoli d'ordi a Catalunya ${ }^{182}$, i 2000 salmes de forment a Tunis ${ }^{183}$.

Bonifaci VIII, que tenia un alt concepte del poder eclesiàstic, que considerava encara que els sobirans, fins i tot en els assuntes polítics, tenien que sometre's a l'autoritat pontíficia i que reivindicava per a la Santa Seu un paper protagonista al context italià, imprimeix un ritme molt ràpit a les negociacions. Durant el primer semestre del 1295, tot aprofitan el cansament dels contendents, disenya uns acords de pau destinats a acontentar totes les parts involucrades en la llarga guerra del Vespro: la Corona Catalanoaragonesa, Nàpols, França i Mallorca. Pel març de 1295, els sobirans aragonés i gal envien els seus delegats a Roma per tal de negociar una pau que tanquès definitivament el llarg contenciòs sicilià ${ }^{184}$.

El projecte d'acord tripartit dissenyat pels assessors del Pontífex intentava restablir les fronteres existents abans de 1282, preveia el retorn de tots els territoris incorporats pels catalans durant la guerra: Sicília, les Illes

\footnotetext{
${ }^{180}$ Jaume II, el 16 de desembre de 1292 , ordena a Berenguer de Vilaragut, Mestre Portulà, que permeti als mercaders de Barcelona, Tarragona, Tortosa, València $i$ Mallorca adquirir cereals a Sicília, per a l'abastement dels respectius mercats locals, a canvi d'una taxa de treta de 3 tarins per salma [ACA, C, reg. 94, fol. 163 r.; ed. A. DE STEFANO-F.GIUNTA, Codice diplomatico di Sicilia, II, n. 326, p. 326].

${ }^{181} \mathrm{~F}$. GiUnta-N. GioRdano-M. SCARLata-L. SCIASCIA, Acta siculo-aragonensia, I-1, Palermo, 1972, docs. 41, 44, 49, 59, 61, 70, 71, 78, 82, 86, 93, 122, 141, 260, 269, 285, 286, $302,303,307,308,309,318,323,326,337,340,341,342,344,345$ i 356.

${ }^{182}$ ACA, C, reg. 261 , fols. 98 r.-98 v.; ed. F. GiUnTA, N. Giordano, M. SCARLATA i L. SCIASCIA, Acta siculo-aragonensia, I-1, doc. 120, p. 104

${ }^{183}$ ACA, C, reg. 261 , fol. 96 v.; Ibidem, doc. 112, p. 98.

${ }^{184} \mathrm{~J}$. ZURITA, Anales de la Corona de Aragón, II, p. 458. V. SALAVERT, Cerdeña, I, pp. 107-108, II, doc. 16, pp. 14-15.
} 
Balears i alguns enclavaments al Mezzogiorno italià. Jaume II, com a rescabalament per aquestes valuoses renúncies, rebria una compensació territorial adient, Sardenya, un extens enclavament situat gairebé al centre mateix de la Mediterrània Occidental, sovintejat per les embarcacions catalanes i mallorquines als seus viatges a Sicília ${ }^{185}$, i que es disputaven des de feia anys -com ja s'ha exposat- pisans i genovesos. Frederic seria recompensat amb una opció de conquesta de l'Imperi Bizantí, mitjançant el seu enllaç amb Catalina Courtenay, hereva del derrer emperador llatí i neta de Carles d'Anjou. Felip IV de França i el seu germà Carles de Valois renunciaven a les seves pretensions sobre la Corona Catalano-aragonesa i es comprometien a evacuar la Vall d'Aran, un petit territori pirinenc, de considerable valor estratègic, ocupat durant la fase inicial de la guerra ${ }^{186}$. El comte-rei, la seva familia i el poble de Sicília es reintegrarian al si de l'Esglesia sense cap mena de sanció espiritual ${ }^{187}$.

Mentre la permuta de les dues illes mediterrànies majors no va provocar, pel fet que els principals perjudicats, els sicilians, els pisans i els genovesos, no participaven en la conferència, grans controvèrsies, els negociadors no van poder possar-se d'acord, en canvi, sobre dues qüestions, les relatives a les evacuacions de les Illes Balears i de la Vall d'Aran. Bonifaci VIII, que el 28 de maig havia exigit infructusoament a l'infant Frederic, a l'entrevista de Velletri, la restitució de Trinàcria a Carles II de Nàpols, minimitza les discordances, per tal d'evitar que la seva iniciativa diplomàtica sucumbís, i presiona les parts, que signen, el 20 de juny a Anagni, els acords assolits i someten els dos disensos pendents a l'arbitratge de la Santa Seu ${ }^{188}$.

\footnotetext{
${ }^{185} \mathrm{Ja}$ el 1277, Pere el Gran havia sol-licitat a les autoritats de Pisa la confirmació dels privilegis de què gaudien els barcelonins a Càller [ACA, reg. 39, fol. 209 r.; ed. V. SALAVERT, Cerdenya, II, doc. 4, pp. 4-5]. La tarida catalana de Pere Cabanes, el desembre de 1283, va recalar a Sardenya, camí de Trapani [ACA, reg. 46, fol. 122 r.-v.; ed. Ibidem, doc. 5, p. 5] A l'abril de 1293, Jaume de Capellades, de Piera, reb, a Barcelona, en comada de Pere de Capellades, 370 quartans d'oli i 24 lliures i mitja de safrà per al viatge que es disposa a emprendre cap a Sardenya i Sicília [ACB, Diversorum, C(d), caixa 10, doc. 429; ed. J.M. MAdURell-A. García, Comandas comerciales barcelonesas, doc. 58, pp. 197-198]. C. BATLLE ha analitzat els primers testimonis documentals de la penetració comercial catalana a l'illa [Noticias sobre los negocios de mercaderes de Barcelona en Cerdenya hacia 1300, "La Sardegna nel mondo mediterraneo", Sàsser, 1978, pp. 277-289].

186J. REGLÁ, Francia, la Corona de Aragón y la frontera pirenaica, Madrid, CSIC, 1951, pp.63-69 i 80-89.

${ }^{187}$ S. RUNCIMAN, I Vespri siciliani, pp. 352-353.

${ }^{188} \mathrm{~V}$. SAlavert, El Tratado de Anagni, pp. 249-260; Cerdeña, I, pp. 107-113.
} 
Els responsables de la política exterior gal-la, conscients de la importància estratègica de l'arxipèlag per l'expansió marítima de la Corona Catalano-aragonesa, condicionen l'evacuació de la vall pirinenca a la reintegració simultània de les Illes al rei de Mallorca, albirant tal volta la sospita que aquesta no arribaria a efectuar-se. El principal enemic d'aquest plantejmanent serà, tanmateix, Bonifaci VIII, empenyat en impossar la seva pau als contendents fins a les darreres conseqüències.

Els gibel-lins italians, davant el perill que implicava per als seus interessos la inciativa papal, sol-liciten a Jaume II -cada cop més involucrat en el contenciós dinàstic castellà- que no retorni Sicilia als angevins ${ }^{189}$. La renúncia pública del sobirà a l'illa, el 30 d'octubre, i l'aixecament paral·lel de l'excomunió que pesava sobre ell i els seus allegats obliguen els sicilians a alinear-se darrera Frederic, que es coronat rei de Sicilia l'11 de desembre de $1295^{190}$.

La negativa dels sículs a aceptar els acords d'Anagni significava la prolongació de la guerra, que d'un conflicte general a escala de la Mediterrània occidental esdevenia, si més no mentre durés l'enfrontament vèneto-lígur a Llevant, un contenciós regional, centrat en torn a l'estret de Messina.

Entre 1285 i 1295 -com ja s'ha exposat- els catalans, mallorquins i valencians s'havien introduit als mercats sicilians, moltes companyies havien destacat factors a l'illa i alguns membres de l'aristocràcia hi havien rebut terres i càrrecs. Frederic III, per tal d'assegurar-se el recolzament dels medis mercatils catalans davant l'imminet trencament d'hostilitats per part dels napolitants, s'apressa a renovar tots els privilegis comercials i aranzelaris que havia concedit Jaume II als barcelonins, i els estén als catalans, mallorquins, valencians $\mathrm{i}$ aragonesos ${ }^{191}$. La nova cort palermitana obre paral·lelament negociacions amb Gènova, on els gibel·lins han aconseguit instaurar el segon doble capitat en les persones de Corrado Doria i Corrado Spinola ${ }^{192}$.

El desafiament de les seves idees teocràtiques per part dels juristes de la cort de Felip IV i la incapacitat dels napolitans per a acabar amb la

\footnotetext{
${ }^{189}$ J. ZURITA, Anales de la Corona de Aragón, II, p. 473-474.

${ }^{190}$ J. ZurITA, Anales de la Corona de Aragón, II, p. 484. S. RunCIMAN, I Vespri siciliani, p. 353. V. Salavert, Cerdeña, I, p. 151

${ }^{191}$ IMHB, Llibre Vert, I, fols. 268-270; ed. C. BATLLE a A DE CAPMANY, Memorias històricas de Barcelona, II-1, doc. 57, pp. 86-88.

${ }^{192} \mathrm{G}$. CARO, Genova sul Mediterraneo, II, pp. 211-213.
} 
revolta sícula indueixen Bonifaci VIII a modificar, durant el primer semestre de 1296, la seva actitut envers Jaume II. La Santa Seu, per a contenir simultàniament els francesos i els sicilians, necessitava un recolzament militar força més efectiu que els dels angevins i aquest només podia ser, donada la seva superioritat naval, el del monarca català, malgrat que aquest hagués estat, fins poc mesos abans, un decidit partidari del bàndol gibel·lí. El Pontífex disposava de medis adients per atreure el comte-rei vers el camp güelf. El 20 de gener el nomena vexillarius, capitaneus et admiratus generalis Ecclesiae ${ }^{193}$. Jaume II, com a contrapartida, ordena als catalans i aragonesos que evacuïn Sicilía. L'ordre del monarca només va ser seguida, emperò, per una part dels afectats; molts de ciutadans dels diversos districtes ibèrics de la "Confederació", ben arrelats al nou territori, van optar per romandre a l'illa. El replegament de la flota reial de Trinàcria senyala el trencament d'hostilitats entre els napolitans i els sicilians. Cada una de les parts només comptava amb els propis efectius; les gran potències navals de la Mediterrània occidental, concentrats els seus efectius en altres contenciosos més importants, es limitaven a seguir a distància els esdeveniments.

Jaume II, estabilitzat el front marítim, intensifica la seva intervenció en el conflicte successori castellà, que la mort de Sanç IV, el 25 d'abril de 1295, ha reactivat. Alfons de la Cerda i el comte-rei renoven a Bordalba l'antiga aliança; el pretendent ofereix al sobirà aragonès, a canvi del seu suport en la conquesta de Castella, el Regne de Múrcia, el comtat de Molina i la plaça de Requena. Les hostilitats s'inicien l'abril de 1296, quan Alfons de la Cerda penetra, per Sòria, a la vall del Duer i el comte-rei ataca les terres alicantines. La doble ofensiva desborda els castellans, que reculen a ambdòs fronts. Els avenços són especialment ràpits a la vall del Segura: els catalans i els aragonesos, entre maig i agost de 1296, ocupen gairebé tot el Regne de Múrcia, per tal que només hi romanen en poder castellà les places fortificades de Lorca, Mula i Alhama ${ }^{194}$.

${ }^{193}$ ACA, Bulas, leg. XX, n. 2. AV, reg. 48, fols. 372 v.-373 r.; ed. V. SALAVERT, Cerdeña, II, doc. 19, pp. 17-20.

${ }^{194} \mathrm{La}$ conquesta de les comarques valencianes de més enllà del Xúquer i del Regne de Múrcia - descrita breument pel cronista coetani, Ramon MUNTANER [Les quatre grans cròniques, pp. 886-887] i amb més detall pel gran historiador aragonès del segle XVI Jerónimo ZURITA [Anales de la Corona de Aragón, II, pp. 500-502]- ha generat una bibliografia considerable, entre la qual destaquen les aportacions de Maria Teresa FERRER [La frontera amb l'Islam en el segle XIV. Cristians i sarraïs al País Velencia, Barcelona, CSIC, 1988; Les aljames sarraïnes de la governació d'Oriola en el segle XIV, Barcelona, CSIC, 1988. Organització $i$ defensa d'un territori fronterer. La governació d'Oriola en el segle XIV, 
Mentre Jaume II conqueria Múrcia, els sicilians desembarcaven a Calàbria i ocupaven algunes places secundàries, com Catanzaro i Cotrone ${ }^{195}$. L'ofensiva de Frederic III preocupa a Roma i obliga al sobirà aragonés a recuperar protagonisme en el conflicte del Mezzogiorno italià. Al febrer de 1297, sol-licita una entrevista al seu germà a Ischia. El Parlament de Sicília examina la qüestió i, en contra del parer de Roger de Llúria, decideix rebutjar l'entrevista entre els dos sobirans. Davant l'evolució dels esdevinements, la vella reina Constança, Roger de Llúria i Juan de Procida, els principals instigadors de l'aixecament sicilià de 1282 contra l'Administració angevina, abandonen l'illa i es dirigeixen a Roma, on Jaume II, poques setmanes després, el 4 d'abril, reb en feu de l'Església Còrcega i Sarden$\mathrm{ya}^{196}$. La concessió pontifícia, llargament preparada, reforçava el poder i el prestigi de Jaume II. L'entesa entre la Santa Seu i la Corona Catalanoaragonesa apuntava al restabliment, després d'assestar un cop definitiu a la resistència dels sicilians i al laicisme de la cort gal·la, d'un nou equilibri a la Mediterrània occidental sota el control directe del Pontífex ${ }^{197}$.

El comte-rei, un cop obtinguda la concessió de iure de Sardenya, retorna immediatement a Catalunya per tal de preparar una flota destinada a reintegrar Sicília al domini teòric de la Santa Seu i efectiu dels napolitans. Des d'aquest moment, el sobirà contempla amb preocupació com els seus interessos, els de tota la Corona Catalano-aragonesa, un Estat mediterrani i ibèric, marítim i continental, entren en conflicte amb els del sector més qualificat dels mercaders i dels armadors catalans, mallorquins i valencians, partidari de continuar freqüentat amb bones condicions les places sicilianes, poc disposat a deixar caure Frederic III davant els angevins, que obririen l'illa a uns altres concurrents, els toscans, i a qui els seria força més difícil arrencar concessions. El comte-rei, per poder conquerir Sardenya, un

Barcelona, CSIC, 1990; La conquesta de les comarques merdionals valencianes per Jaume II, "Quaderns de Migjorn", 3 (Alacant, en premsa)], de Juan Manuel del EsTAL [Conquista y anexión de las tierras de Alicante. Elche, Orihuela y Guardamar al Reino de Valencia por Jaime II de Aragón (1296-1308). Alacant, Caja de Ahorros Provincial, 1982; Corpus documental del Reino de Murcia bajo la soberanía de Aragón (1296-1304/5), Alacant, Instituto de Estudios "Juan Gil Albert", 1985; El Reino de Murcia bajo Aragón (1296-1305), Alacant, Instituto de Estudios "Juan Gil Albert", 1990] i de José HINOJOSA, [Textos para la Historia de Alicante. Historia Medieval, Alacant, Instituto de Cultura "Juan Gil Albert", 1990].

${ }^{195}$ J. ZURITA, Anales de la Corona de Aragón, II, pp. 506-513.

${ }^{196} \mathrm{~V}$. SAlavert, Cerdeña, I, pp, 117-121, II, doc. 21, pp. 22-30.

${ }^{197}$ F. GIUNTA, Aragoneses $i$ catalanes, p. 64. 
enclavament d'un induptable valor estratègic i escàs interés econòmic, i incrementar paral-lelament, tot aprofitant les transitòries dificultats internes de Castella, el pes específic de la "Confederació" a la Península Ibèrica, es veia obligat a comprometre la presència dels seus súbdits en un mercat amb una capacitat d'oferta i de demanda considerables, el sicilià. La política mediterrània de Jaume II, des d'Anagni, s'allunya de la de Pere el Gran, el seu centre gravitatori es desplaça cap a Occident, es trasllada de Trinàcria a Sardenya. La nova illa constiteuix, per als assessors del sobirà, la plataforma indispensable per a que la presència política i naval de la Corona d'Aragó a la conca occidental del Mare Nostrum s'afermi, per a que la projecció comercial ultramarina catalana hi pugui superar la concurrència genovesa ${ }^{198}$. Els plantejaments reials, que supeditaven l'expansió mercantil a la político-militar, la concessió d'avantatges fiscals i comercials a la conquesta o a l'amenaça militar prèvies de la plaça, devien trobar ressó entre l'aristocràcia feudal i les capes menys innovadores i tècnicament preparades de la burgesia.

\section{CONCLUSIONS}

Els genovesos, des de la conquesta de les Illes Balears, consideraven Catalunya com una potència naval emergent, amb un nivell tecnològic considerable però no amenaçador per al seus interessos a ultramar. L'annexió de Sicília, que va significar un important salt qualitatiu en la projecció militar i mercantil de la "Confederació" a la Mediterrània, va repercutir negativament, tanmateix, en les relacions de Barcelona amb la capital de la Ligúria .

Pere el Gran, conscient de la precarietat del seu domini damunt el nou territori, de la seva inferioritat naval respecte a les dues grans Repúbliques marineres de l'Itàlia septentrional, de la dependència estructural del mercat lígur dels excedents frumentaris sículs i de l'important paper que jugaven els ports de Trinàcria en la xarxa de les vies marítimes de la "Dominant", no va modificar el favorable estatut fiscal i mercantil de què gaudien els genovesos a l'illa. La neutralitat en la guerra del Vespro permetia a la Diarquia gibel-lina conjurar l'hostilitat de la Santa Seu i de França,

\footnotetext{
${ }^{198}$ V. SalAVERT, Cerdeña, I, pp. 176-179. F. GiUnTA, Aragoneses $i$ catalanes, p. 59.
} 
garantir als seus súbdits el lliure accés als mercats napolitans, provençals $\mathrm{i}$ sicilians, concentrar els seus efectius en la pugna amb Pisa per la supremacia a la mar Tirrena i preservar els seus interessos a les Illes Balears.

L'extensió dels seus privilegis aranzelaris i comercials als mercaders catalans, mallorquins i valencians a Sicília i la caiguda de la seva participació en el comerç exterior illenc alarmen, del 1285 ençà, els rectors del Comune. La penetració de la flota barcelonina al Tirrè, atreta pel dèficit de nòlits creat a Pisa pel triomf genovès a la Melòria, desencadena ja una guerra de cors contra les embarcacions catalanes. La rèplica dels efectats no es fa esperar. Els incidents, protagonitzats per particulars, degraden però no trenquen les relacions diplomàtiques bilaterals. Gènova considera prioritari el seu contenciós amb Pisa pel domini de l'àrea tirrena i pel control dels recursos de Sardenya. L'antagonista principal de la Corona Catalano-aragonesa és el regne de Nàpols, interessat a recuperar Sicília. La necessitat de mantenir ambdós contenciosos separats obliga les autoritats de la República i de la "Confederació" a dosificar l'agressivitat dels respectius súbdits, per tal que no transmutin un concurrent orc en un enemic palès. La ubicació dels incidents dibuixa dues àrees calentes. Els genovesos tendeixen a concetrar els seus atacs a la Tirrena septentrional, en el quadrilàter comprès entre Bonifacio, Civitavecchia, Portovenere i Mònaco. Els súbdits ibèrics i ultramarins de Jaume II, en canvi, desencadenen preferentment les seves ofensives a la mar Jònica i al canal de Sicília, per on han de passar les flotes italianes tan a l'anada com a la tornada de Llevant o d'Ifriqiya.

Sicília es van convertint en un mercat on els genovesos, tot conservant l'estatut de nació més afavorida, topen, des del 1291, amb uns concurrents nous però agressius, els catalans. Trinàcria, fins llavors terra segura i de bons negocis, esdevé gradualment per als lígurs, durant la darrera dècada de la centúria, la plataforma d'un sistema de paranys estretàgicament situada en la xarxa de les seves rutes marítimes.

La tensió entre Gènova i Barcelona no va assolir, tanmateix, unes quotes suficients com per a que l' "Executiu" lígur, abandonant el neutralisme practicat per les dues primeres Diarquies gibel-lines, acceptés les propostes d'aliança ofertes, a la darreria de 1292, per Carles II de Nàpols.

La incorporació de Sicilía havia beneficiat els mercaders catalans, pel fet de refermar la seva penetració a ambdues conques de la Mediterrània, els fradristerns de la noblesa i del patriciat urbà del Principat, que hi van rebre beneficis $i$ càrrecs ben retribuïts, $i$ les capes mitjanes $i$ baixes de les ciutats marítimes de la "Confederació", per tal com hi va atenuar les oscil·lacions 
del preu del blat i va estimular alhora la producció d'alguns sectors manufacturers. Les despeses de la llarga guerra marítima distorsionaven, tanmateix, l'assignació de recursos a la Corona Catalano-aragonesa i hi incrementaven la presió fiscal. La concentració del gros de la flota i dels efectius militars al Mezzogiorno impedia a la Monarquia aragonesa aprofitar les favorables perspectives d'expansió territorial que la complicada successió d'Alfons X de Castella obria a la Península Ibèrica. La incapacitat de Nàpols per recuperar Sicília i reforçar el prestigi internacional de la Santa Seu, incita, per altra part, Bonifaci VIII a buscar un braç armat més efectiu, a iniciar un acostament a la Monarquia aragonesa.

Durant el primer semestre 1295, els esdeveniments s'acceleren: Jaume II, a canvi de una renúncia a Sícilia i a les Illes Balears que no hi comprometia l'activitat mercantil dels seus súbdits i del rebuig dels plantejaments gibel-lins, obté l'aixecament de l'interdicte, el càrrec de defensor de l'Església i la infeudació de Sardenya. La guerra del Vespro sicilià, com a conseqüència dels acords d'Anagni, es tranforma de conflicte internacional en divergència regional. La tensió es trasllada gradualment de la conca occidental del Mare Nostrum a l'oriental.

\section{RÉSUMÉ}

Suite à l'annexion de Sicile en 1282 , la presence économique et politique de la Couronne d'Aragon dans la Méditerranée s'est beaucoup renforcée. L'annexion a favorisé la pénétration des catalans dans le marché d'outremer et suscité, par la suite, la méfiance des génois. En Italie le front gibelin s'est réactivé. Dans les deux dernières décennies du XIII ${ }^{\mathrm{e}}$ siècle, la confédération franco-angevine, avec le soutien de la Papauté, a essayé de regagner l'île par la force. Au même temps, Gênes et Pise se battaient pour avoir la suprématie dans la mer Tyrrhénienne et en Sardaigne. Chacune des quatre parties bélligerantes concentrait leurs navires dans son propre conflit et observait avec attention les mouvements des contraires. La tension est arrivée a tel niveau qu'elle finît pour ballaster le commerce, une nouvelle guerre de course entre catalans et génois étant née dans la Méditerranée centrale. Après 1295, lorque Jacques II a obtenû du pape Boniface VIII le titre de "Défenseur de l'Église" et l'île de Sardaigne en fief, la situation s'est beaucoup delâchée, Pise étant alors confinée à une puissance de deuxième range. Le roi d'Aragon, en échange, fût obligé à renoncer au plan gibelin et à la possession de Sicile dans des conditions qui ne lésaient point l'activité marchande de ses sujets. 


\section{SUMMARY}

The annexation of Sicily to the Crown of Aragon in 1282 re-enforced the economical and political presence of the latter in the Mediterranean Sea and allowed the Catalans to penetrate the foreign markets, aroused suspicions in Genoa and reactivated the Ghibelin party in Italy.

During the two last decades of XIIIth century, the Franco-Angevin league, with the support of the Holy See, tried to regain Sicily by force of arms. At the same time, Genoa and Pisa contended for supremacy in the Tyrhenian Sea and in Sardinia. Both conflicts occurred together and each one of the four belligerent parties concentrated their ships in their own quarrel and, at the same time, observed attentively the movements of the others. The political tension reached such high levels that, at the end, it harmed international commerce as a result of a war of piracy between Catalans and Ligurians in the Central Mediterranean. After 1297, the situation calmed down little by little, when since Pisa was a second-class power, James II of Aragon obtained from Pope Bonifacio VIII the post of "Defender of the Church and the feudal status of Sardinia, but he himself had to give back Sicily, being sure that their subjects' business would not suffer any damage, and also had to give up his Ghibelline plans. 